U.S. Department of the Interior

U.S. Geological Survey

\title{
Use of Thematic Mapper Imagery to Assess Water Quality, Trophic State, and Macrophyte Distributions in Massachusetts Lakes
}

By MARCUS C. WALDRON, PETER A. STEEVES, and

JOHN T. FINN (Department of Forestry and Wildlife Management, University of Massachusetts, Amherst)

Water-Resources Investigations Report 01-4016

Prepared in cooperation with the

Massachusetts Department of Environmental Management

Northborough, Massachusetts

2001 


\section{U.S. DEPARTMENT OF THE INTERIOR \\ GALE A. NORTON, Secretary}

U.S. GEOLOGICAL SURVEY
Charles G. Groat, Director

The use of trade or product names in this report is for identification purposes only and does not constitute endorsement by the U.S. Government.

For additional information write to:

Chief, Massachusetts-Rhode Island District

U.S. Geological Survey

Water Resources Division

10 Bearfoot Road

Northborough, MA 01532

or visit our web site at

http://ma.water.usgs.gov
Copies of this report can be purchased from:

U.S. Geological Survey Branch of Information Services

Box 25286

Denver, CO 80225-0286 


\section{CONTENTS}

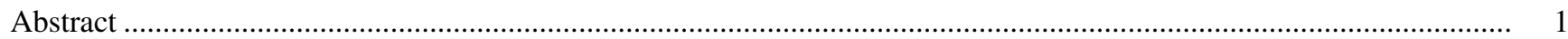

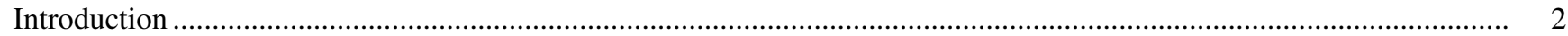

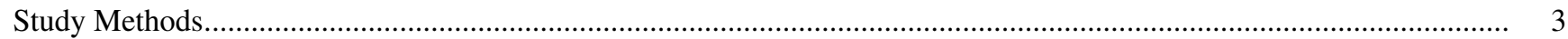

Sampling and Analysis for Water-Quality Characteristics .............................................................................. 5

Field Observations ......................................................................................................................... 5

Phytoplankton-Chlorophyll Concentration ........................................................................................... 5

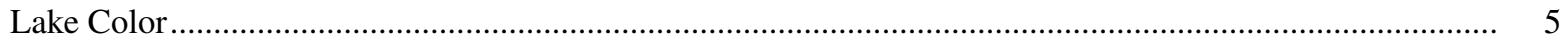

Dissolved Organic Carbon Concentration................................................................................................ 8

Analytical Quality Assurance .................................................................................................................... 8

Quality Assurance of Volunteer Data ....................................................................................................... 9

Thematic Mapper-Based Assessment of Water Quality and Trophic State............................................................... 13

Secchi Disk Transparency and Phytoplankton-Chlorophyll Concentration ............................................................ 13

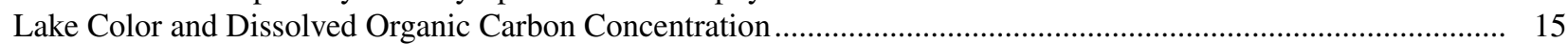

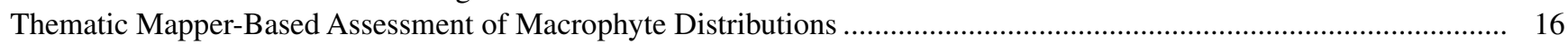

Field-Mapping of Macrophyte Distributions ............................................................................................ 16

Digitization and Processing of Field Maps .............................................................................................. 17

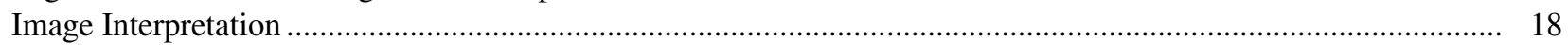

Observed Versus Predicted Macrophyte Distributions ........................................................................................ 19

1996 Predictions Based on 1996 Interpretations ................................................................................... 19

1997 Predictions Based on 1997 Interpretations ...................................................................................... 19

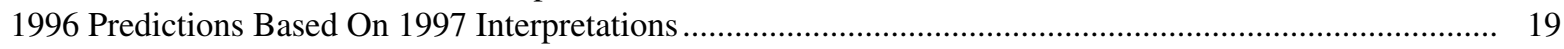

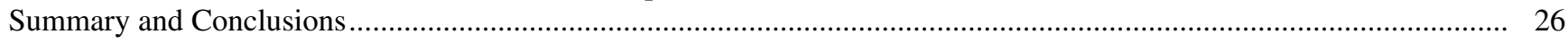

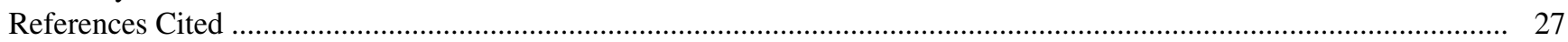

\section{FIGURES}

1. Map showing locations of study lakes and Landsat-5 Worldwide Reference System paths and rows for

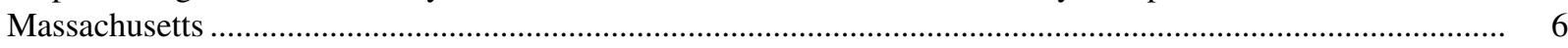

2. Example of field form used in volunteer field-data collection program .......................................................... 10

3. Graphs showing relations between volunteer and U.S. Geological Survey staff measurements of (A) Secchi disk transparency; $(B)$ phytoplankton-chlorophyll concentration; $(C)$ color; and $(D)$ surfacewater temperature

4, 5. Graphs showing:

4. Relations between Secchi disk transparency and phytoplankton-chlorophyll concentration in Massachusetts lakes in (A) 1996; (B) 1997; and (C) 1998

5. Relations between color and dissolved organic carbon concentration in Massachusetts lakes ................... 16

6. Graphs comparing observed (field-mapped in summer 1996) and predicted (interpreted from July 1996 Thematic Mapper data) areal coverages of four aquatic macrophyte cover classes coverages in 12 Massachusetts lakes.....

7. Maps showing observed (field-mapped in summer 1996) and predicted (interpreted from July 1996 Thematic Mapper data) areal coverages of four aquatic macrophyte cover classes coverages in Whitehall Reservoir, Hopkinton, Massachusetts

8. Graphs comparing observed (field-mapped in summer 1997) and predicted (interpreted from August 1997 Thematic Mapper data) areal coverages of four aquatic macrophyte cover classes coverages in 12 Massachusetts lakes

9. Maps showing observed (field-mapped in summer 1997) and predicted (interpreted from August 1997 Thematic Mapper data) areal coverages of four aquatic macrophyte cover classes coverages in Thompson Pond, Spencer, Massachusetts ..... 
10. Graphs comparing observed (field-mapped in summer 1996) and predicted (interpreted from August 1997 Thematic Mapper data) areal coverages of four aquatic macrophyte cover classes coverages in 12 Massachusetts lakes

11. Maps showing observed (field-mapped in summer 1996) and predicted (interpreted from August 1997

Thematic Mapper data) areal coverages of four aquatic macrophyte cover classes coverages in East

Brimfield Reservoir, Brimfield and Sturbridge, Massachusetts

\section{TABLES}

1. Thematic Mapper spectral bands

2. Massachusetts lakes for which the distributions of floating, emergent, and submerged macrophytes were mapped in 1996, 1997, and 1998 for calibration of Landsat-5 Thematic Mapper imagery

3. Lakes sampled by Massachusetts Water Watch Partnership volunteers concurrently with U.S. Geological Survey staff for chlorophyll concentration, Secchi disk transparency, color, and water temperature in 1997 and 1998.

4. Landsat-5 Thematic Mapper scenes used to assess water quality and trophic state of Massachusetts lakes

5. Thematic Mapper spectral bands and combinations of bands used as models to test for correlations with water-quality and trophic-state data for Massachusetts lakes

Massachusetts lakes sampled in 1996, 1997, and 1998, and numbers of measurements of water-quality characteristics used to calibrate Landsat-5 Thematic Mapper imagery

7. Lake-water-quality data collected within 24 hours of Landsat-5 Thematic Mapper imaging of the lakes, and haze-corrected digital numbers corresponding to the station locations in the images.....

\section{CONVERSION FACTORS, VERTICAL DATUM, AND ABBREVIATED WATER-QUALITY UNITS}

\section{CONVERSION FACTORS}

\begin{tabular}{ccl}
\hline Multiply & By & To obtain \\
\hline centimeter $(\mathrm{cm})$ & 0.3937008 & inch (in.) \\
cubic meter $\left(\mathrm{m}^{3}\right)$ & 264.17205 & gallon $(\mathrm{gal})$ \\
cubic meter $\left(\mathrm{m}^{3}\right)$ & 35.31467 & cubic foot $\left(\mathrm{ft}^{3}\right)$ \\
hectare $(\mathrm{ha})$ & 2.471 & acre \\
kilometer $(\mathrm{km})$ & 0.62137 & mile $(\mathrm{mi})$ \\
meter $(\mathrm{m})$ & 3.280840 & foot $(\mathrm{ft})$ \\
milliliter $(\mathrm{mL})$ & 0.00026417 & gallon $(\mathrm{gal})$ \\
Water temperature is reported in degree Celsius $\left({ }^{\circ} \mathrm{C}\right)$, which can be converted \\
\multicolumn{2}{c}{ to degree Fahrenheit $\left({ }^{\circ} \mathrm{F}\right)$ by the following equation: } \\
\multicolumn{2}{c}{} \\
\hline
\end{tabular}

Very small units of length are reported in millimeters $(\mathrm{mm})$, micrometers $(\mu \mathrm{m})$, or nanometers (nm). One centimeter equals $10 \mathrm{~mm}, 1 \mathrm{~mm}$ equals $1,000 \mu \mathrm{m}$, and $1 \mu \mathrm{m}$ equals $1,000 \mathrm{~nm}$.

\section{VERTICAL DATUM}

Sea level: In this report, "sea level" refers to the National Geodetic Vertical Datum of 1929 (NGVD of 1929)—a geodetic datum derived from a general adjustment of the first-order level nets of the United States and Canada, formerly called Sea Level Datum of 1929.

\section{ABBREVIATED WATER-QUALITY UNITS:}

Chemical concentration is reported in milligrams per liter $(\mathrm{mg} / \mathrm{L})$ or micrograms per liter $(\mu \mathrm{g} / \mathrm{L})$. Milligrams per liter is a unit expressing the concentration of chemical constituents in solution as mass (milligrams) of solute per unit volume (liter) of water. One thousand micrograms per liter is equivalent to one milligram per liter. For concentrations less than $7,000 \mathrm{mg} / \mathrm{L}$, the numerical value is the same as for concentrations in parts per million. Specific electrical conductance of water is reported in microsiemens per centimeter at 25 degrees Celsius $(\mu \mathrm{S} / \mathrm{cm})$. Color is reported in platinum-cobalt units (PCU). 


\title{
Use of Thematic Mapper Imagery to Assess Water Quality, Trophic State, and Macrophyte Distributions in Massachusetts Lakes
}

\author{
By Marcus C. Waldron, Peter A. Steeves, and John T. Finn
}

\section{Abstract}

During the spring and summer of 1996, 1997, and 1998, measurements of phytoplanktonchlorophyll concentration, Secchi disk transparency, and color were made at 97 Massachusetts lakes within 24 hours of Landsat Thematic Mapper imaging of the lakes in an effort to assess water quality and trophic state. Spatial distributions of floating, emergent, and submerged macrophytes were mapped in 49 of the lakes at least once during the 3-year period. The maps were digitized and used to assign pixels in the thematic mapper images to one of four vegetation cover classes - open water, 1-50 percent floating-andemergent-vegetation cover, 51-100 percent floating-and-emergent-vegetation cover, and submerged vegetation at any density. The field data were collected by teams of U.S. Geological Survey and Massachusetts Department of Environmental Management staff and by 76 volunteers. Side-by-side sampling by U.S. Geological Survey and volunteer field teams resulted in statistically similar chlorophyll determinations, Secchi disk readings, and temperature measurements, but concurrent color determinations were not similar, possibly due to contamination of sample bottles issued to the volunteers.

Attempts to develop predictive relations between phytoplankton-chlorophyll concentration, Secchi disk transparency, lake color, dissolved organic carbon, and various combinations of thematic mapper bands 1,2,3, and 4 digital numbers were unsuccessful, primarily because of the extremely low concentrations of chlorophyll in the lakes studied, and also because of the highly variable dissolved organic carbon concentrations.

Predictive relations were developed between Secchi disk transparency and phytoplanktonchlorophyll concentration, and between color and dissolved organic carbon concentration. Phytoplankton-chlorophyll concentration was inversely correlated with Secchi disk transparency during all three sampling periods. The relations were very similar in 1996 and 1997 and indicated that 62 to 67 percent of the variability in Secchi disk transparency could be explained by the chlorophyll concentration. Analysis of color and dissolved organic carbon concentrations in water samples collected by U.S. Geological Survey field teams in 1996-98 indicated that 91 percent of the variance in color in Massachusetts lakes can be explained by variations in dissolved organic carbon.

Areas of open-water, submerged vegetation, and two surface-vegetation-cover classes predicted from Thematic Mapper images acquired in the summer of 1996 closely matched the areas observed in a set of field observations. However, the same analysis applied to a set of data acquired in the summer of 1997 resulted in somewhat less reliable predictions, and an attempt to predict 1996 vegetation-cover areas using the relations developed in the 1997 analysis was unsuccessful. 


\section{INTRODUCTION}

Accelerated eutrophication due to changing drainage-basin activities is a significant problem affecting Massachusetts lakes (Massachusetts Water Resources Commission, 1994). This accelerated, or cultural, eutrophication is caused by nutrient-rich effluents from sewage treatment plants, runoff of fertilizers and animal wastes, stormwater runoff from impervious surfaces, leaching from septic systems, and increased soil erosion resulting from construction and other similar activities. Cultural eutrophication can lead to excessive growth of aquatic macrophytes, increased turbidity, depletion of dissolved oxygen, and subsequent loss of fish habitat. Massachusetts lakes are especially susceptible to the problem because most drainage basins are heavily developed and most lakes are subject to multiple uses. In addition, many lakes in Massachusetts were created or enlarged by impounding water behind dams, resulting in submerged soils within these impoundments that may provide an additional source of nutrients affecting the trophic state of the lakes. Trophic state, the extent of the effect of eutrophication due to nutrient enrichment, has been difficult to quantify in Massachusetts because many lakes develop dense beds of aquatic macrophytes in response to eutrophication, and most methods for assessing trophic state are based on the relative abundance of phytoplankton algae and do not take into account the biomass of macrophytes (Canfield and others, 1983).

The recently adopted Massachusetts Policy on Lake and Pond Management advocates a comprehensive approach to lake eutrophication that integrates education, watershed protection, and in-lake management in an attempt to reconcile desired uses of Massachusetts lakes with their ability to support those uses (Massachusetts Water Resources Commission, 1994). Central to the Massachusetts Policy on Lake and Pond Management is the need to assess lake-water quality at regular intervals and to identify trends (both negative and positive) in lake trophic state. With more than 3,000 named lakes, ponds, and reservoirs (for simplicity, the word "lake" will be used throughout this report to refer to any open body of water) in Massachusetts, the costs and logistical problems associated with a statewide lake-quality-monitoring program are substantial.

The development of satellite resources such as the Landsat Thematic Mapper (TM) and new techniques for processing and analyzing satellite data offer the potential for augmenting the data-collection and resource-evaluation efforts of State environmental agencies. Landsat images can provide high-resolution information concerning a number of important limnologic features, including chlorophyll- $a$ concentration, turbidity, color, algal production rates, nutrient concentrations, and surface-water temperatures (Scarpace and others, 1979; Verdin, 1985; Raitala, 1986; Shimoda and others, 1986). The availability of Landsat images dating back to the early 1970s allows for the development of long-term records of properties related to lake trophic state and can be used to identify trends (Witzig and Whitehurst, 1981; Lillesand and others, 1983).

The U.S. Geological Survey (USGS), in cooperation with the Massachusetts Department of Environmental Management (MADEM), has investigated the use of Landsat TM data for Statewide assessment of lake quality and trophic state. Measurements of water temperature, Secchi disk transparency, color, and the concentration of phytoplankton chlorophyll were made in 97 lakes during the summers of 1996, 1997, and 1998, by USGS and MADEM staff and by a team of trained volunteers recruited by the Massachusetts Water Watch Partnership (MassWWP). The lake measurements were timed to coincide with Landsat-5 TM imaging of the State. During the same period, the midto-late-summer distributions of floating, emergent, and submerged macrophytes were mapped in 62 lakes, again by a combination of professional and volunteer field teams. The field data were correlated with data extracted from a set of four TM images, each image representing the eastern two-thirds of the State. 
The purpose of this report is to demonstrate how Landsat TM data may be used to assess the water quality and trophic state of Massachusetts lakes and to monitor the distributions of aquatic macrophytes. The report describes methods of fielddata collection and procedures used for acquiring and processing the TM data. Field data collected by volunteer water-quality monitoring teams are compared statistically with concurrent measurements made by USGS field teams. Results are presented separately for TM-based assessment of lake-water quality and trophic state and for TM-based mapping of lake-macrophyte distributions. Data collected during the study are available via the World Wide Web at http://ma.water.usgs.gov/lakesandponds/.

The authors wish to thank the volunteers and staff of the Massachusetts Water Watch Partnership for their generous contributions of time and other resources to this project.

\section{STUDY METHODS}

Landsat-5 orbits the earth at an altitude of $705 \mathrm{~km}$ in a near-polar, sun-synchronous orbit with a 16-day, 233-orbit repeat cycle. The primary imaging instrument on Landsat-5 is the TM, which senses reflected light energy in seven spectral bands, three in the visible range, three in the near- and mid-infrared, and one in the thermal infrared (table 1). The TM sensors have a spatial resolution of 120-by-120 m for the thermal-infrared band and 30-by-30 $\mathrm{m}$ for the other six spectral bands. The sensors can distinguish 256 levels of brightness (radiance) in each spectral band for each 30 -by-30 m or 120 -by-120 m picture element (pixel). The brightness levels are recorded as digital numbers (DNs) representing the average radiance measured over the ground area corresponding to each pixel.

Table 1. Thematic Mapper spectral bands

\begin{tabular}{|c|c|c|c|}
\hline $\begin{array}{l}\text { Spectral } \\
\text { band }\end{array}$ & $\begin{array}{l}\text { Wavelength range } \\
\text { (micrometers) }\end{array}$ & $\begin{array}{l}\text { Nominal spectral } \\
\text { location }\end{array}$ & Principal Application(s) \\
\hline 1 & $0.45-0.52$ & Blue-green & $\begin{array}{l}\text { Designed for maximum penetration of water. Used for bathymetric mapping of } \\
\text { shallow water bodies. Also used for distinguishing soil from vegetation and } \\
\text { deciduous from coniferous trees. }\end{array}$ \\
\hline 2 & $0.52-0.60$ & Green & $\begin{array}{l}\text { Designed to measure green reflectance peak of vegetation. Useful for assessing } \\
\text { plant vigor. }\end{array}$ \\
\hline 3 & $0.63-0.69$ & Red & $\begin{array}{l}\text { Designed to measure light that is strongly absorbed by chlorophyll. Used for } \\
\text { discriminating vegetation types. }\end{array}$ \\
\hline 4 & $0.76-0.90$ & Near infrared & $\begin{array}{l}\text { Useful for determining vegetation types, vigor, and biomass. Also used for } \\
\text { distinguishing shorelines of water bodies. }\end{array}$ \\
\hline 5 & $1.55-1.75$ & Mid-infrared & $\begin{array}{l}\text { Measures moisture content of soil and vegetation. Penetrates thin clouds. Used } \\
\text { to distinguish snow from clouds. }\end{array}$ \\
\hline 6 & $10.4-12.5$ & Thermal infrared & $\begin{array}{l}\text { Nighttime images are useful for thermal mapping and for estimating soil } \\
\text { moisture. }\end{array}$ \\
\hline 7 & $2.08-2.35$ & Mid-infrared & $\begin{array}{l}\text { Measures absorption by hydroxyl ions in minerals. Used for mapping } \\
\text { hydrothermally altered rocks associated with mineral deposits. Also sensitive } \\
\text { to vegetation moisture content. }\end{array}$ \\
\hline
\end{tabular}


Landsat imagery is subdivided into scenes based on a Worldwide Reference System (WRS) consisting of vertical paths and horizontal rows. Each combination of path and row describes a unique 185-by-170-kilometer rectangle of ground-surface area. The State of Massachusetts is represented by WRS paths 11, 12, and 13, and by rows 30 and 31 (fig. 1); however, because adjacent paths overlap by as much as 40 percent, most of the State appears in paths 12 and 13. If the images are shifted north along the two paths, then about 90 percent of the State can be imaged in only two scenes.

Use of TM imagery to assess lake quality and trophic state requires that predictive relations be developed between measured water-quality characteristics and the TM data. Ideally, these relations are based on measurements made at or close to the time of TM-data acquisition on a large number of lakes exhibiting the range of conditions likely to be encountered in the State. The 16-day Landsat-5 orbital repeat cycle provides about 10 opportunities for image acquisition between May 1 and September 30. However, the number of lakes that could be sampled during each flyover was limited by the small number of State and USGS personnel, boats, and equipment available for use in the study. The solution to this problem was to engage the Massachusetts Water Watch Partnership (MassWWP), which is affiliated with the University of Massachusetts and the Massachusetts Water Resources Research Center in Amherst, Mass., to recruit and train volunteers to sample lakes throughout the State.

A total of 76 individuals participated as volunteers during the three spring-summer sampling periods. Twenty-one volunteers were involved in the first sampling period (1996), 61 during the second sampling period (1997), and 39 during the third sampling period (1998). All volunteers were trained in lake-sampling and sample-processing techniques in a series of hands-on training sessions conducted each spring by MassWWP, MADEM, and USGS staff. Equipment was provided to the volunteers for measuring Secchi disk transparency, for collecting and processing water samples to be analyzed for color and phytoplankton-chlorophyll concentration, and for mapping distributions of macrophytes in the lakes.

The volunteers' efforts greatly increased the amount of water-quality data collected concurrently with TM image acquisition. MADEM and USGS field personnel collected data at 94 stations on 65 lakes and volunteers collected data at 68 stations on 48 lakes. Sixteen of the lakes were sampled jointly by USGS and volunteers for quality assurance purposes. Volunteers were able to collect data each time the satellite was overhead from May through September. Most of the lakes sampled by MADEM and USGS could be sampled only once due to resource limitations. A list of the study lakes, their locations, and the numbers and kinds of water-quality measurements made during the three study periods is presented in table 6 (at back of report). In addition, distributions of floating, emergent, and submerged macrophytes were mapped in 49 lakes at least once during the study either by volunteers or by professional field personnel (table 2).

Selection of the study lakes was determined partly by the study requirement that the lakes be representative of lakes throughout the State and partly by other circumstances, including the affiliations and interests of the volunteers and the program requirements of the MADEM. Most of the volunteers live close to the lakes they sampled. The MADEM collected data primarily from lakes in State parks, forests, and reservations. Additional lakes were added to the list to ensure that the full range of trophic and waterquality conditions were represented in the data set. The lakes ranged in surface area from 4 to 696 ha with a median surface area of $36 \mathrm{ha}$. Seventy-five percent of the lakes had surface areas of 81 ha or less. Maximum depths of the lakes ranged from 2 to $30 \mathrm{~m}$ with a median of $7 \mathrm{~m}$. Seventy-five percent of the lakes were less than $10 \mathrm{~m}$ deep. 


\section{Sampling and Analysis for Water-Quality Characteristics}

Sampling stations were established over the deepest part of each study lake. For lakes with surface areas greater than about 81 ha, or with multiple basins, as many as six stations were established and monitored separately. Stations either were marked with a buoy or were located by aligning two pairs of landmarks on the shore spaced at a 90 degree angle relative to the station. Exact locations (latitude and longitude) of stations sampled by USGS field teams were determined by a global positioning system (GPS). All other stations were marked on appropriate USGS 1:25,000-scale topographic sheets and their locations determined with a digitizer.

Orbital schedules for Landsat-5 were obtained for each study period from the Earth Observation Satellite Company (EOSAT) in Lanham, Md. Sampling usually was scheduled for the morning of the flyover to coincide with the 9:45 a.m. equatorial crossing of the satellite, although data collected up to 24 hours before or after image acquisition were considered acceptable.

\section{Field Observations}

Upon arriving at a station, samplers completed a field form (fig. 2) in which they identified the lake and the station, and recorded maximum depth, percent cloud cover, barometric pressure, and air temperature. Surface-water temperature was measured either with a digital thermometer or with a standard alcohol thermometer. Secchi disk transparency was determined by lowering a standard 20-centimeter Secchi disk into the water and noting the exact depth at which it disappeared, then raising the disk and noting the depth at which it reappeared. The Secchi disk transparency was recorded as the mean of the two readings to the nearest $0.1 \mathrm{~m}$. Exact times of all field observations were recorded on the field sheet.

\section{Phytoplankton-Chlorophyll Concentration}

Water samples for phytoplankton-chlorophyll determinations were collected by hand in brown plastic 1-liter bottles from a depth of about $0.25 \mathrm{~m}$ below the surface. The samples were returned on ice to shore where measured volumes were filtered onto $47 \mathrm{~mm}$ Watman GF/F glass-fiber filters using a maximum suction pressure of 0.5 atmospheres. The filters were folded in half and placed in a drying chamber where they were air dried at room temperature for 30 minutes. The dried filters were wrapped in aluminum foil and mailed overnight to the Environmental Analytical Laboratory at the University of Massachusetts, Amherst, for analysis. In the laboratory, the filters were ground in alkalized 90-percent acetone and analyzed spectrophotometrically for chlorophyll- $a$ and phaeophytin- $a$ concentrations (American Public Health Association and others, 1995). For the purposes of this study, the phytoplankton-chlorophyll concentration was considered to be the sum of the measured chlorophyll- $a$ and phaeophytin- $a$ concentrations.

\section{Lake Color}

Filtrate produced during field processing of the chlorophyll samples was transferred to clean, prelabeled glass or polyethylene bottles, which were shipped on ice overnight to the University of Massachusetts, Amherst, for analysis of color. Lake color was determined spectrophotometrically in a 5 -centimeter cell at a wavelength of $425 \mathrm{~nm}$. The measured absorbance was converted to platinum-cobalt units (PCU) with a standard curve (American Public Health Association and others, 1995). 


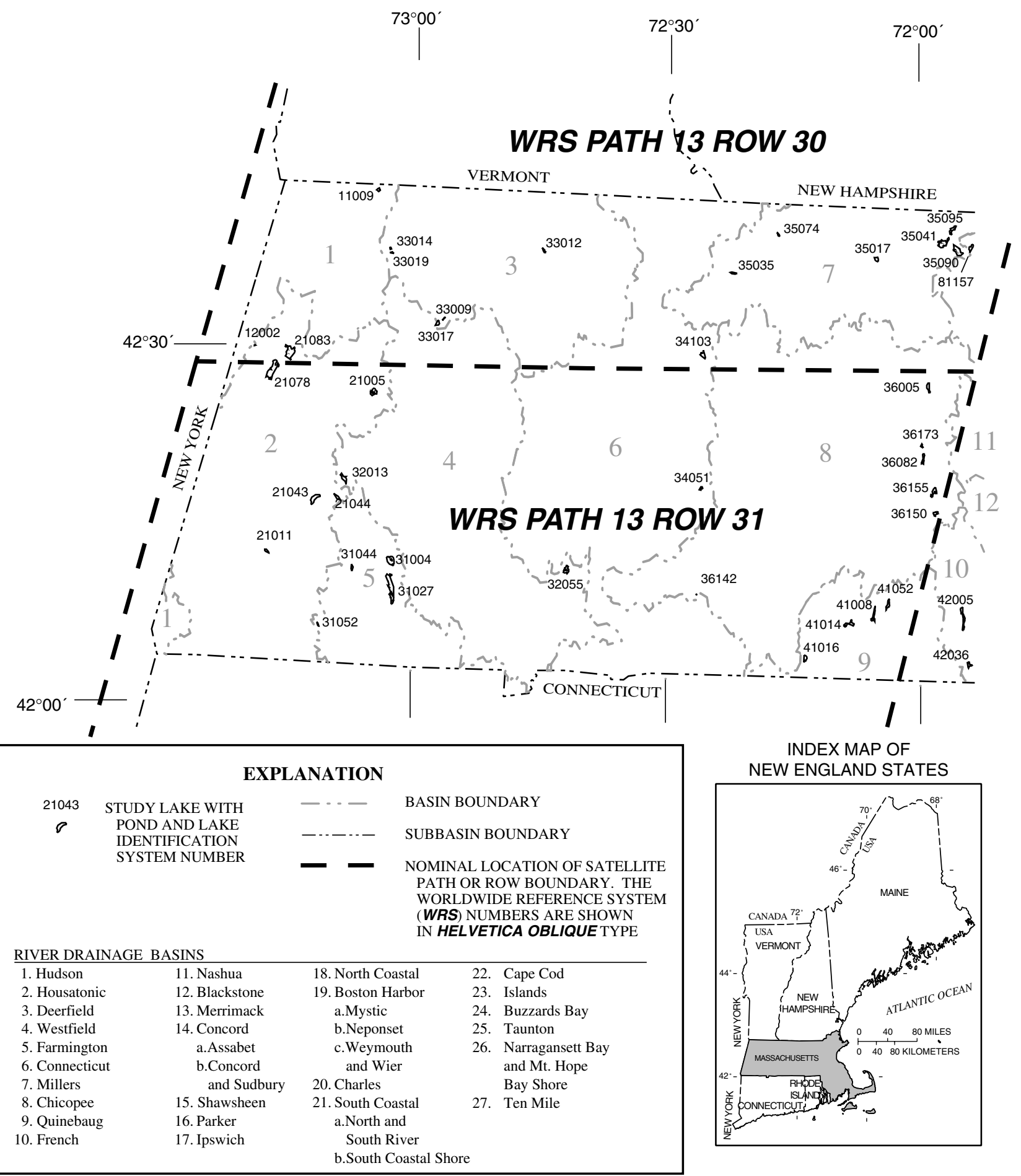

Figure 1. Locations of study lakes and Landsat-5 Worldwide 


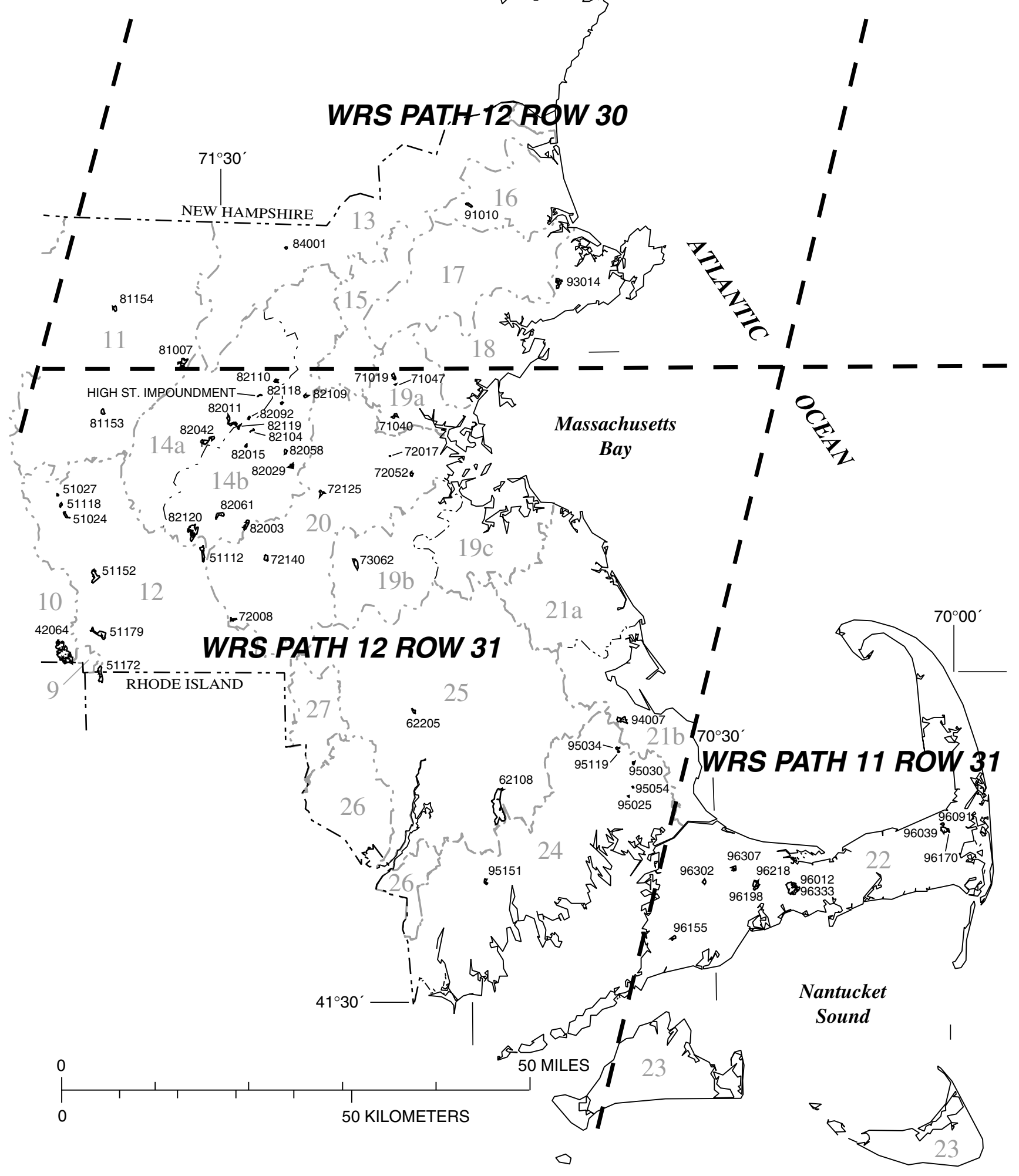

Reference System paths and rows for Massachusetts. 
Table 2. Massachusetts lakes for which the distributions of floating, emergent, and submerged aquatic macrophytes were mapped in 1996, 1997, and 1998 for calibration of Landsat-5 Thematic Mapper imagery

[PALIS, Pond and Lake Identification System; X, mapped; blank space, not mapped; ---, no assigned code]

\begin{tabular}{|c|c|c|c|c|c|c|c|c|c|c|}
\hline \multirow[b]{2}{*}{ Lake name } & \multirow{2}{*}{$\begin{array}{l}\text { PALIS } \\
\text { code }\end{array}$} & \multicolumn{3}{|c|}{1996} & \multicolumn{3}{|c|}{1997} & \multicolumn{3}{|c|}{1998} \\
\hline & & Floating & $\begin{array}{c}\text { Emer- } \\
\text { gent }\end{array}$ & $\begin{array}{c}\text { Sub- } \\
\text { merged }\end{array}$ & Floating & $\begin{array}{c}\text { Emer- } \\
\text { gent }\end{array}$ & $\begin{array}{c}\text { Sub- } \\
\text { merged }\end{array}$ & Floating & $\begin{array}{c}\text { Emer- } \\
\text { gent }\end{array}$ & $\begin{array}{c}\text { Sub- } \\
\text { merged }\end{array}$ \\
\hline Althea Lake & 84002 & $\mathrm{X}$ & $\mathrm{X}$ & $\mathrm{X}$ & & & & & & \\
\hline Ashmere lake & 21005 & $\mathrm{X}$ & $\mathrm{X}$ & $\mathrm{X}$ & & & & & & \\
\hline Bare Hill Pond (USGS) & 81007 & & & & & & & $\mathrm{X}$ & $\mathrm{X}$ & $\mathrm{X}$ \\
\hline Bare Hill Pond (USGS) & 81007 & & & & & & & $\mathrm{X}$ & $\mathrm{X}$ & \\
\hline Bearse Pond & 96012 & & & & $\mathrm{X}$ & $\mathrm{X}$ & & & & \\
\hline Big (Benton) Pond & 31004 & $\mathrm{X}$ & $\mathrm{X}$ & $\mathrm{X}$ & & & & & & \\
\hline Buckley-Dunton Lake & 32013 & $\mathrm{X}$ & $\mathrm{X}$ & $\mathrm{X}$ & & & & & & \\
\hline Charge Pond & 95025 & & $\mathrm{X}$ & $\mathrm{X}$ & & & & & & \\
\hline Chebacco Lake & 93014 & $\mathrm{X}$ & $\mathrm{X}$ & $\mathrm{X}$ & & & & & & \\
\hline Coes Reservoir & 51024 & & & & $\mathrm{X}$ & $\mathrm{X}$ & $\mathrm{X}$ & & & \\
\hline Cook Pond & 51027 & & & & $\mathrm{X}$ & & $\mathrm{X}$ & & & \\
\hline Curlew Pond & 95034 & $\mathrm{X}$ & $\mathrm{X}$ & $\mathrm{X}$ & & & & & & \\
\hline Dudley Pond & 82029 & $\mathrm{X}$ & & $\mathrm{X}$ & & & & & & \\
\hline East Brimfield Reservoir (East) & 41014 & $\mathrm{X}$ & $\mathrm{X}$ & $\mathrm{X}$ & & & & & & \\
\hline East Brimfield Reservoir (West) & 41014 & $\mathrm{X}$ & $\mathrm{X}$ & $\mathrm{X}$ & & & & & & \\
\hline Fearing Pond & 95054 & $\mathrm{X}$ & $\mathrm{X}$ & $\mathrm{X}$ & & & & & & \\
\hline Goose Pond & 21043 & & & & & & & $\mathrm{X}$ & $\mathrm{X}$ & $\mathrm{X}$ \\
\hline Greenwater Pond & 21044 & $\mathrm{X}$ & $\mathrm{X}$ & $\mathrm{X}$ & & & & & & \\
\hline Heard Pond & 82058 & & & & & & & $\mathrm{X}$ & $\mathrm{X}$ & $\mathrm{X}$ \\
\hline High Street Impoundment & --- & & & & $\mathrm{X}$ & $\mathrm{X}$ & $\mathrm{X}$ & & & \\
\hline Horn Pond & 71019 & $\mathrm{X}$ & $\mathrm{X}$ & $\mathrm{X}$ & $\mathrm{X}$ & $\mathrm{X}$ & $\mathrm{X}$ & $\mathrm{X}$ & $\mathrm{X}$ & $\mathrm{X}$ \\
\hline Mauserts Pond & 11009 & $\mathrm{X}$ & $\mathrm{X}$ & $\mathrm{X}$ & & & & & & \\
\hline Merino Lake & 42036 & & & & $\mathrm{X}$ & $\mathrm{X}$ & $\mathrm{X}$ & & & \\
\hline Metacomet Lake & 34051 & $\mathrm{X}$ & & $\mathrm{X}$ & & & & & & \\
\hline Onota Lake & 21078 & & & & & & $\mathrm{X}$ & & & \\
\hline
\end{tabular}

\section{Dissolved Organic Carbon Concentration}

Samples for DOC determinations were filtered through $0.45-\mu \mathrm{m}$-pore-size silver filters into baked brown-glass bottles using a stainless steel filtration system. The samples were then stored on ice prior to analysis. DOC determinations were carried out by the Environmental Analytical Laboratory at the University of Massachusetts, Amherst. Analysis of DOC was by wet oxidation with carbon dioxide detection by infrared spectroscopy (Fishman and Friedman, 1989).

\section{Analytical Quality Assurance}

Twelve sets of duplicate samples were collected at various sampling sites during the study and analyzed separately for DOC by the USGS National Water Quality Laboratory and the University of Massachusetts Environmental Analytical Laboratory. Differences between DOC determinations by the two laboratories ranged from 18 to 40 percent with a mean of 26 percent. Concentration differences among 12 duplicate determinations made by the Environmental Analytical Laboratory ranged from 0 to 18 percent with a mean of 
Table 2. Massachusetts lakes for which the distributions of floating, emergent, and submerged aquatic macrophytes were mapped in 1996, 1997, and 1998 for calibration of Landsat-5 Thematic Mapper imagery-Continued

\begin{tabular}{|c|c|c|c|c|c|c|c|c|c|c|}
\hline \multirow[b]{2}{*}{ Lake name } & \multirow{2}{*}{$\begin{array}{l}\text { PALIS } \\
\text { code }\end{array}$} & \multicolumn{3}{|c|}{1996} & \multicolumn{3}{|c|}{1997} & \multicolumn{3}{|c|}{1998} \\
\hline & & Floating & $\begin{array}{c}\text { Emer- } \\
\text { gent }\end{array}$ & $\begin{array}{c}\text { Sub- } \\
\text { merged }\end{array}$ & Floating & $\begin{array}{c}\text { Emer- } \\
\text { gent }\end{array}$ & $\begin{array}{c}\text { Sub- } \\
\text { merged }\end{array}$ & Floating & $\begin{array}{c}\text { Emer- } \\
\text { gent }\end{array}$ & $\begin{array}{c}\text { Sub- } \\
\text { merged }\end{array}$ \\
\hline Patch Reservoir & 51118 & & & & $\mathrm{X}$ & $\mathrm{X}$ & $\mathrm{X}$ & & & \\
\hline Pequot Pond & 32055 & $\mathrm{X}$ & $\mathrm{X}$ & $\mathrm{X}$ & & & & & & \\
\hline Pontoosuc Lake & 21083 & & & & & & & & & \\
\hline Puffer Pond (USGS) & 82092 & & & & & & & $\mathrm{X}$ & $\mathrm{X}$ & $\mathrm{X}$ \\
\hline Puffer Pond & 82092 & & & & $\mathrm{X}$ & $\mathrm{X}$ & & $\mathrm{X}$ & $\mathrm{X}$ & \\
\hline Rocky Pond & 95119 & $\mathrm{x}$ & $\mathrm{X}$ & $\mathrm{x}$ & & & & & & \\
\hline Spy Pond & 71040 & & & & & $\mathrm{x}$ & $\mathrm{x}$ & & & \\
\hline Sugden Reservoir & 36150 & & & & $\mathrm{X}$ & $\mathrm{x}$ & & $\mathrm{X}$ & $\mathrm{X}$ & $\mathrm{X}$ \\
\hline Thompson Pond & 36155 & $\mathrm{x}$ & $\mathrm{X}$ & $\mathrm{X}$ & $\mathrm{X}$ & $\mathrm{x}$ & & $\mathrm{X}$ & $\mathrm{x}$ & $\mathrm{X}$ \\
\hline Upper Spectacle Pond & 31044 & $\mathrm{x}$ & $\mathrm{X}$ & $\mathrm{x}$ & & & & & & \\
\hline Waban Lake & 72125 & $\mathrm{x}$ & $\mathrm{X}$ & $\mathrm{x}$ & $\mathrm{x}$ & $\mathrm{x}$ & $\mathrm{x}$ & $\mathrm{x}$ & $\mathrm{x}$ & $\mathrm{X}$ \\
\hline Walden Pond & 82109 & & & & & & & $\mathrm{X}$ & $\mathrm{X}$ & $\mathrm{X}$ \\
\hline Wallum Lake (lower) & 51172 & & $\mathrm{X}$ & $\mathrm{X}$ & & & & & & \\
\hline Warners Pond & 82110 & & & & $\mathrm{X}$ & $\mathrm{x}$ & $\mathrm{X}$ & & & \\
\hline Webster Lake & 42064 & & & & $\mathrm{x}$ & $\mathrm{x}$ & & & & \\
\hline Wequaquet Lake & 96333 & & & & $\mathrm{x}$ & $\mathrm{x}$ & $\mathrm{x}$ & & & \\
\hline White Pond (Concord) & 82118 & $\mathrm{x}$ & $\mathrm{X}$ & $\mathrm{x}$ & $\mathrm{x}$ & $\mathrm{x}$ & $\mathrm{x}$ & & & \\
\hline Whitehall Reservoir (NE) & 82120 & $\mathrm{x}$ & $\mathrm{X}$ & $\mathrm{x}$ & & & & & & \\
\hline Whitehall Reservoir (NW) & 82120 & $\mathrm{x}$ & $\mathrm{X}$ & $\mathrm{x}$ & & & & & & \\
\hline Whitehall Reservoir (SW) & 82120 & $\mathrm{x}$ & $\mathrm{X}$ & $\mathrm{x}$ & & & & & & \\
\hline Winnekeag Lake & 81157 & & & & & & & $\mathrm{x}$ & $\mathrm{x}$ & \\
\hline Winter Pond & 71047 & $\mathrm{x}$ & $\mathrm{X}$ & $\mathrm{X}$ & $\mathrm{x}$ & $\mathrm{x}$ & $\mathrm{X}$ & $\mathrm{X}$ & $\mathrm{x}$ & $\mathrm{X}$ \\
\hline Winthrop Lake & 72140 & $\mathrm{x}$ & $\mathrm{X}$ & $\mathrm{x}$ & & & & $\mathrm{X}$ & $\mathrm{x}$ & $\mathrm{X}$ \\
\hline York Lake & 31052 & $\mathrm{x}$ & $\mathrm{X}$ & $\mathrm{x}$ & & & & & & \\
\hline
\end{tabular}

7 percent. Color determinations made on the same sets of duplicates differed by 4 to 10 percent with a mean of 6 percent.

Twelve sets of duplicate phytoplankton chlorophyll samples were analyzed during the study period by the University of Massachusetts Environmental Analytical Laboratory. The percent difference between duplicates ranged from 7 to 100 and the mean percent difference was 28 . The highest percent differences were obtained from samples with extremely low chlorophyll concentrations (less than $1.0 \mu \mathrm{g} / \mathrm{L}$ ).

\section{Quality Assurance of Volunteer Data}

Measurements of phytoplankton-chlorophyll concentration, Secchi disk transparency, color, and water temperature were made simultaneously at 26 stations on 16 lakes (table 3 ) by USGS and volunteer field teams to determine the reproducibility and reliability of the data. Measurements usually were made from the same boat. Samples were processed separately by each team and were shipped together to the analytical laboratory. 


\section{USGS-MADEM-MassWWP Lake and Pond FIELD DATA}

Name of Lake: PALIS Code:

Station No:

Lat: Long:

Sampled By: Date:

Field Measurements

ns =not sampled

Time of Measurement

Maximum Depth: meters/feet

Cloud Cover: $\%$

Barometric Pressure: $\mathrm{mmHg} / \mathrm{inHg}$ am/pm

Air Temperature: ${ }^{\circ} \mathrm{C} /{ }^{\circ} \mathrm{F}$ $\mathrm{am} / \mathrm{pm}$

Surface Water Temperature: ${ }^{\circ} \mathrm{C} /{ }^{\circ} \mathrm{F}$ Secchi Disk Depth: meters/feet $a m / p m$ am/pm am/pm

\section{Water Samples Collected}

Date/Time of Sample:

Collection

Preparation

Shipping

Vol. Filtered (L)

Chlorophyll:

Color:

DOC:

\section{Remarks}

\begin{tabular}{lc} 
Multiply & Conversions \\
Feet & by \\
Gallons & 0.3048 \\
Atmospheres & 3.7853 \\
Pounds/sq in & 760 \\
\hline
\end{tabular}

Temperature can be converted to degrees Celsius $\left({ }^{\circ} \mathrm{C}\right)$ from degrees Fahrenheit $\left({ }^{\circ} \mathrm{F}\right)$ by the following equation: ${ }^{\circ} \mathrm{C}=\left({ }^{\circ} \mathrm{F}-32\right) / 1.8$

Figure 2. Example of field form used in volunteer field-data collection program. 
Table 3. Lakes sampled by Massachusetts Water Watch Partnership volunteers concurrently with U.S. Geological Survey staff for chlorophyll concentration, Secchi disk transparency, color, and water temperature in 1997 and 1998

[Raw data available on the Internet at http://water.usgs.gov. PALIS, Pond and Lake Identification System; USGS, U.S. Geological Survey; X, water samples collected or measurements made concurrently; --, not measured]

\begin{tabular}{|c|c|c|c|c|c|c|c|c|c|c|c|}
\hline \multirow{2}{*}{ Lake name } & \multirow{2}{*}{$\begin{array}{l}\text { Sampling } \\
\text { station }\end{array}$} & \multirow{2}{*}{$\begin{array}{l}\text { PALIS } \\
\text { code }\end{array}$} & \multicolumn{3}{|c|}{ Chlorophyll } & \multicolumn{2}{|c|}{ Secchi } & \multicolumn{2}{|c|}{ Color } & \multicolumn{2}{|c|}{$\begin{array}{c}\text { Water } \\
\text { Temperature }\end{array}$} \\
\hline & & & $\begin{array}{l}\text { Sampling } \\
\text { date }\end{array}$ & USGS & WWP & USGS & WWP & USGS & WWP & USGS & WWP \\
\hline Long Pond & 1 & 62108 & $8-27-97$ & $\mathrm{X}$ & $X$ & -- & -- & $\mathrm{X}$ & $X$ & $X$ & $\mathrm{X}$ \\
\hline Long Pond & 2 & 62108 & $8-27-97$ & $\mathrm{X}$ & $X$ & -- & -- & $\mathrm{X}$ & $\mathrm{X}$ & $\mathrm{X}$ & $\mathrm{X}$ \\
\hline Long Pond & 3 & 62108 & $8-27-97$ & $\mathrm{X}$ & $X$ & -- & -- & $\mathrm{X}$ & $\mathrm{X}$ & $X$ & $\mathrm{X}$ \\
\hline Long Pond & 4 & 62108 & $8-27-97$ & $\mathrm{X}$ & $X$ & -- & -- & $\mathrm{X}$ & $\mathrm{X}$ & $X$ & $\mathrm{X}$ \\
\hline Long Pond & 5 & 62108 & $8-27-97$ & $\mathrm{X}$ & $\mathrm{X}$ & -- & -- & $\mathrm{X}$ & $\mathrm{X}$ & $\mathrm{X}$ & $\mathrm{X}$ \\
\hline Long Pond & $\begin{array}{l}\text { Deep } \\
\text { hole }\end{array}$ & 62108 & $8-27-97$ & -- & -- & $X$ & $X$ & -- & -- & -- & -- \\
\hline Lower Naukeag Lake & 1 & 35041 & $8-04-98$ & $\mathrm{X}$ & $\mathrm{X}$ & $\mathrm{X}$ & $\mathrm{X}$ & -- & -- & $\mathrm{X}$ & $\mathrm{X}$ \\
\hline Onota Lake & 1 & 21078 & $6-01-98$ & $\mathrm{X}$ & $X$ & $\mathrm{X}$ & $\mathrm{X}$ & $\mathrm{X}$ & $\mathrm{X}$ & $X$ & $\mathrm{X}$ \\
\hline Onota Lake & 3 & 21078 & $6-01-98$ & $\mathrm{X}$ & $X$ & $\mathrm{X}$ & $X$ & $\mathrm{X}$ & $\mathrm{X}$ & $\mathrm{X}$ & $\mathrm{X}$ \\
\hline Pontoosuc Lake & 1 & 21083 & $6-01-98$ & $\mathrm{X}$ & $\mathrm{X}$ & $\mathrm{X}$ & $\mathrm{X}$ & $\mathrm{X}$ & $\mathrm{X}$ & $\mathrm{X}$ & $\mathrm{X}$ \\
\hline Stearns Mill Pond & 1 & 82104 & $7-12-98$ & $\mathrm{X}$ & $X$ & -- & -- & $\mathrm{X}$ & $X$ & $\mathrm{X}$ & $\mathrm{X}$ \\
\hline Upper Naukeag lake & 1 & 35090 & 8-04-98 & $\mathrm{X}$ & $X$ & $\mathrm{X}$ & $X$ & $X$ & $X$ & $X$ & $\mathrm{X}$ \\
\hline Wallum Lake & 1 & 51172 & $6-10-98$ & $\mathrm{X}$ & $X$ & $\mathrm{X}$ & $X$ & $\mathrm{X}$ & $X$ & $X$ & $\mathrm{X}$ \\
\hline Watatic Lake & 1 & 35095 & 8-04-98 & $X$ & $X$ & $X$ & $X$ & $X$ & $\mathrm{X}$ & $X$ & $\mathrm{X}$ \\
\hline Webster Lake & 1 & 42064 & $6-10-98$ & $\mathrm{X}$ & $\mathrm{X}$ & $\mathrm{X}$ & $\mathrm{X}$ & $\mathrm{X}$ & $\mathrm{X}$ & $\mathrm{X}$ & $\mathrm{X}$ \\
\hline Webster Lake & 2 & 42064 & $6-10-98$ & $X$ & $X$ & $X$ & $X$ & $\mathrm{X}$ & $X$ & $X$ & $\mathrm{X}$ \\
\hline White Pond (Concord) & 1 & 82118 & $8-13-98$ & $\mathrm{X}$ & $X$ & $\mathrm{X}$ & $\mathrm{X}$ & $\mathrm{X}$ & $\mathrm{X}$ & $X$ & $\mathrm{X}$ \\
\hline White Pond (Hudson/Stow) & 1 & 82119 & $7-12-98$ & $\mathrm{X}$ & $X$ & $X$ & $X$ & $\mathrm{X}$ & $X$ & $X$ & $\mathrm{X}$ \\
\hline Whitins Reservoir & 1 & 51179 & $6-10-98$ & $\mathrm{X}$ & $X$ & $\mathrm{X}$ & $X$ & $\mathrm{X}$ & $X$ & $X$ & $\mathrm{X}$ \\
\hline Whitins Reservoir & 2 & 51179 & $6-10-98$ & $X$ & $X$ & $X$ & $X$ & $X$ & $X$ & $X$ & $X$ \\
\hline Willet Pond & 1 & 73062 & $7-28-98$ & $\mathrm{X}$ & $X$ & $\mathrm{X}$ & $\mathrm{X}$ & $\mathrm{X}$ & $\mathrm{X}$ & $X$ & $\mathrm{X}$ \\
\hline Winnekeag Lake & 1 & 81157 & 8-04-98 & $\mathrm{X}$ & $X$ & $X$ & $X$ & $\mathrm{X}$ & $X$ & $X$ & $X$ \\
\hline
\end{tabular}

Comparisons of measurement results obtained by the two sampling teams are presented in figures $3 A$ through $3 B$. There was good agreement between volunteer and USGS Secchi disk transparency determinations (fig. 3A). The percent difference between the two sets of measurements ranged from 0 to 24 and the mean percent difference was 8 . The two sets of phytoplankton-chlorophyll determinations were more variable (fig. $3 B$ ). Percent differences ranged from 7 to 54 and the mean was 24 percent. At concentrations greater than $7 \mu \mathrm{g} / \mathrm{L}$, the USGS samples consistently yielded $2-3 \mu \mathrm{g} / \mathrm{L}$ more chlorophyll than did the volunteer samples.

Agreement between color measurements made on USGS and volunteer water samples was not good (fig. 3C). Differences ranged from 2 to 200 percent. The mean percent difference was 72 . The large differences may have resulted from inadequate cleaning of the volunteer sample containers. All USGS samples were submitted to the laboratory in baked glass bottles while volunteer samples were submitted in polyethylene bottles that had been used in a previous investigation.

Comparisons of water temperature measurements were reasonably good (fig. $3 D$ ), given the fact that different types of measuring devices were used. Percent differences between USGS and volunteer measurements ranges from 0 to 17 with a mean of 3 percent. 

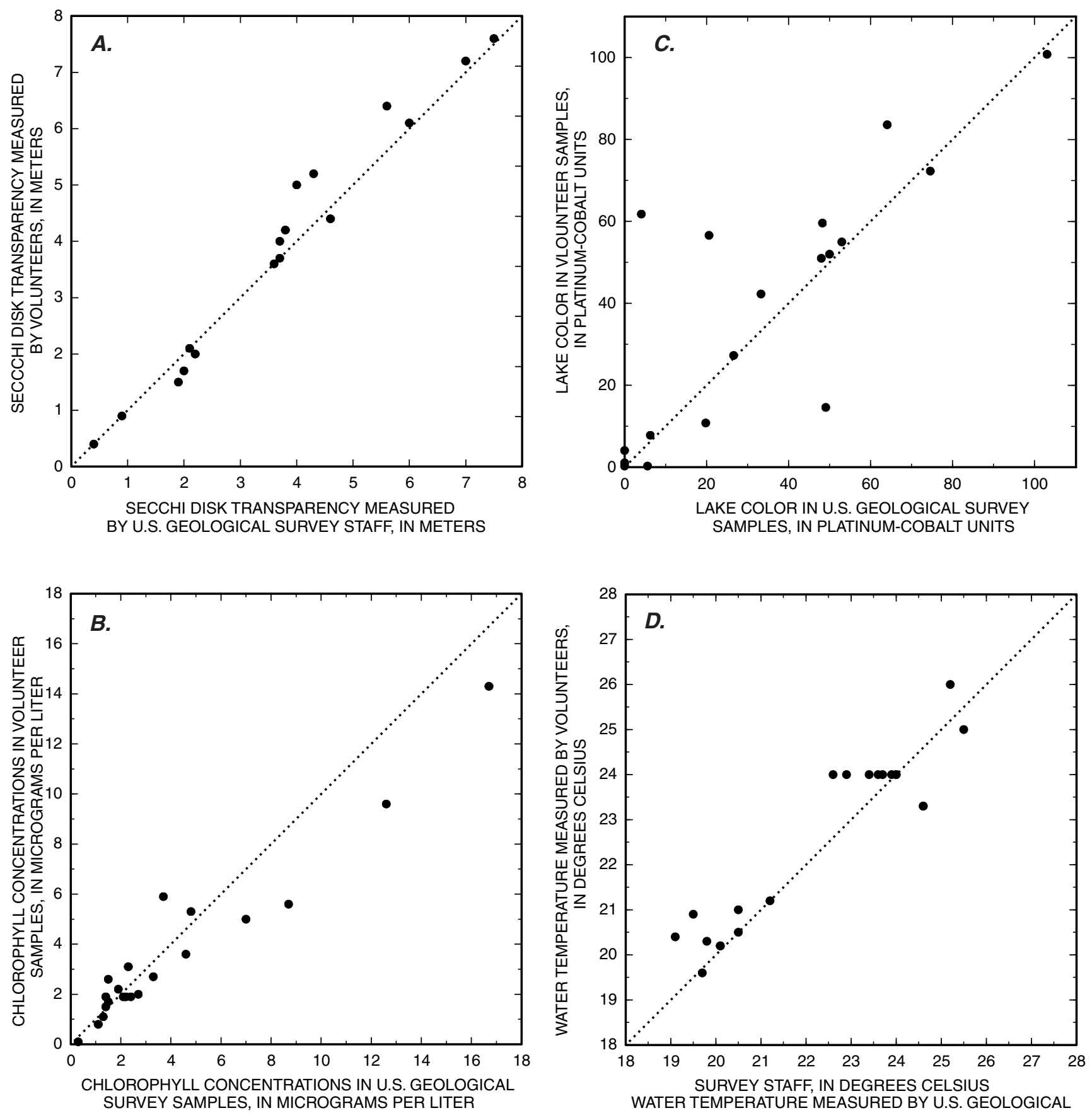

Figure 3. Relations between volunteer and U.S. Geological Survey staff measurements of $(A)$ Secchi disk transparency; $(B)$ phytoplankton-chlorophyll concentration; $(C)$ color; and $(D)$ surface-water temperature. (Dotted line is line of one-to-one correspondence of paired measurements.) 
THEMATIC MAPPER-BASED

ASSESSMENT OF WATER QUALITY AND TROPHIC STATE

At the end of each spring-summer study period, the available TM images were examined and ranked according to their degree of atmospheric interference due to haze and cloud cover, and the amount of lakewater-quality data available for correlation with pixel brightness values. On this basis, four scenes were purchased from the USGS Earth Resources Observation Systems (EROS) Data Center (EDC) in Sioux Falls, South Dakota. Scene identification codes and other descriptive information are presented in table 4.

Each scene comprises picture elements (pixels) representing either 30-by-30 m (for visible and reflectedinfrared (IR) wave bands) or 120-by-120 m (for the thermal-IR wave band) ground-resolution cells. This study used data from visible TM wave bands 1 (TM1, $0.45-0.52 \mu \mathrm{m}$ ), 2 (TM2, 0.52-0.60 $\mu \mathrm{m}$ ), and 3 (TM3, $0.63-0.69 \mu \mathrm{m}$ ), and reflected-IR wave band 4 (TM4, 0.76-0.90 $\mu \mathrm{m})$. Data for each pixel consist of digital numbers (DNs) ranging from 0 to 255 that represent the recorded intensity of reflected radiation in one of the wave bands. The scenes were radiometrically and geometrically corrected, rotated, and aligned to state plane coordinates by the EDC.

Lake-water-quality data collected within 24 hours of acquisition of each TM scene were compiled and the brightness values for pixels corresponding to the station locations were extracted from the TM images. Brightness values for the three visible bands (TM1, TM2, and TM3) were then corrected for haze by regressing them against the corresponding values for

Table 4. Landsat-5 Thematic Mapper scenes used to assess water-quality and trophic state of Massachusetts lakes

[EDC, Earth Resources Observation Systems (EROS) Data Center; WRS, Worldwide Reference System]

\begin{tabular}{cccc}
\hline $\begin{array}{c}\text { EDC scene } \\
\text { identification }\end{array}$ & $\begin{array}{c}\text { Image } \\
\text { acquisition } \\
\text { date }\end{array}$ & $\begin{array}{c}\text { WRS } \\
\text { path }\end{array}$ & $\begin{array}{c}\text { WRS } \\
\text { row }\end{array}$ \\
\hline LT5012031009620410 & $7-22-66$ & 012 & 031.00000 \\
LT5013030009720610 & $6-23-97$ & 012 & 030.97174 \\
LT5012030009723810 & $8-26-97$ & 012 & 030.97000 \\
LT5012031009816110 & $6-10-98$ & 012 & 031.98000 \\
\hline
\end{tabular}

the reflected-IR band (TM4). In the absence of scattering due to haze and other atmospheric irregularities, the intercepts of the regression lines should pass through the origin (Wilkie and Finn, 1996). In all four scenes, the regression lines intercepted the TM4 axes at some positive value, indicating the need for correction. The band was adjusted by the amount that the intercept shifted from the origin (Wilkie and Finn, 1996). The corrected TM values, plus the corresponding lakewater-quality data used in the analysis, are presented in table 7 (at back of report).

\section{Secchi Disk Transparency and Phytoplankton-Chlorophyll Concentration}

Phytoplankton-chlorophyll concentration was inversely correlated with Secchi disk transparency during all three sampling periods (fig. 4). The regression equations for the relations in 1996 and 1997 were similar, and indicated that 62 to 67 percent of the variability in Secchi disk transparency could be explained by the chlorophyll concentration. The unexplained variability is due to a combination of sampling and analytical errors, variations in lake color, and the presence of suspensoids other than phytoplankton algae (Goldman and Horne, 1983).

The relation was shifted significantly in the 1998 dataset. The slope of the regression line was similar to that calculated for the previous two years, but the yintercept was nearly doubled, so that chlorophyll concentrations associated with a given Secchi disk transparency increased by an average of 135 percent over the previous two years. The apparent increase may be related to a change in the analytical instrumentation used in the Environmental Analysis Laboratory that year.

Secchi disk transparency values and phytoplankton-chlorophyll data corresponding to the four TM scenes were analyzed using simple linear regression to develop relations that could be used to predict the water-quality characteristics from the TM data. Twenty-eight combinations of haze-corrected DNs for TM bands 1, 2, 3, and 4 were used as models in the analysis (table 5). The analytical approach was to plot 


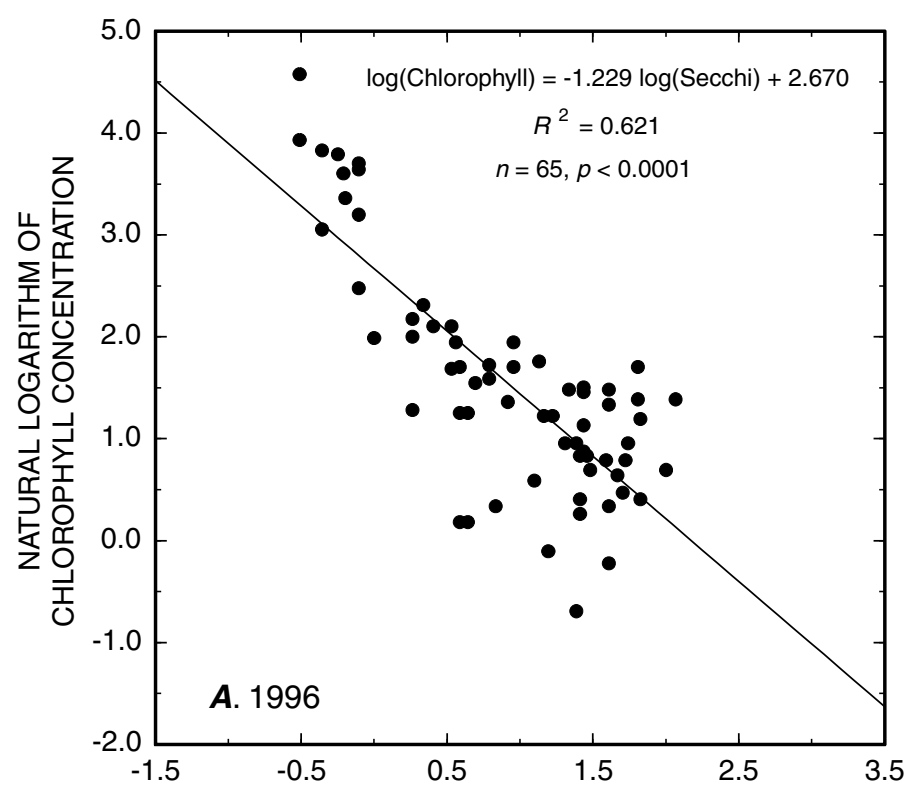

NATURAL LOGARITHM OF SECCHI DISK TRANSPARENCY

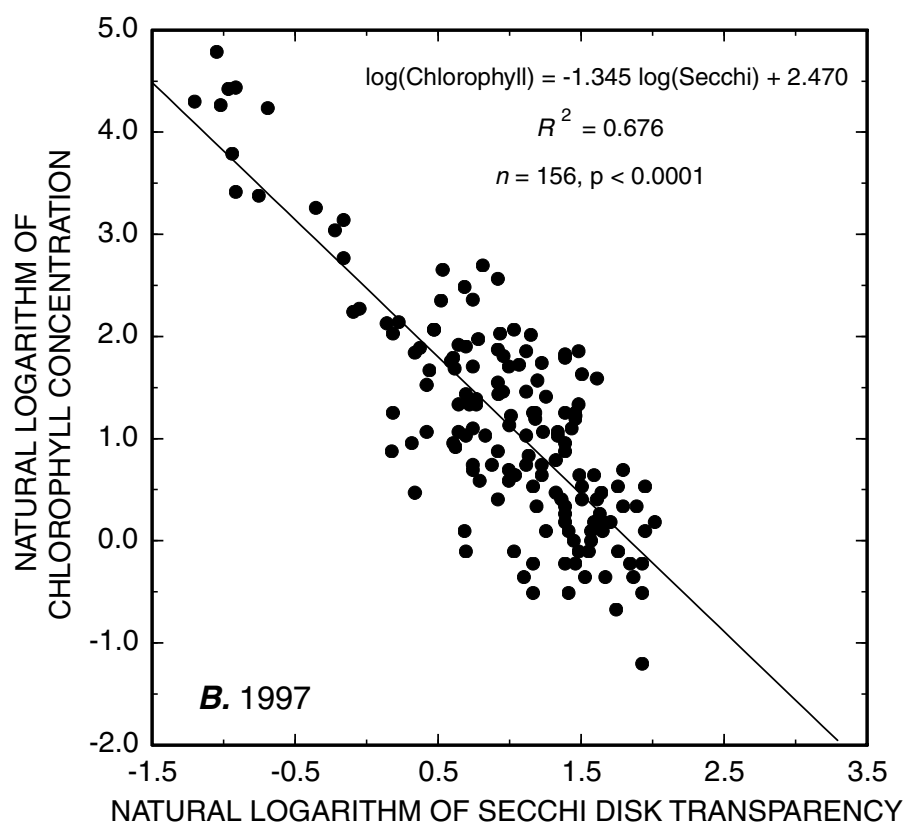

Figure 4. Relations between Secchi disk transparency and phytoplankton-chlorophyll concentration in Massachusetts lakes in (A) 1996; (B) 1997; and (C) 1998.

the natural logarithms of the Secchi disk transparencies versus the phytoplankton-chlorophyll concentrations for a given scene to determine if the expected inverse relation existed between the two datasets. Obvious outliers were discarded and the remaining natural-logtransformed lake data were regressed against each of the TM models listed in table 5. No relations were observed that could be applied consistently to all the scenes and only a few of the models explained more than 60 percent of the variability in either the chlorophyll or the Secchi disk data.

The lack of any predictive relations between the TM data and phytoplankton-chlorophyll concentration or Secchi disk transparency was surprising given the long history of successful use of TM data to predict the water quality and trophic state of inland waters. Beginning with the work of Lathrop and Lillesand (1986), who used some of the earliest available TM data to assess chlorophyll concentration, Secchi disk transparency, turbidity, and the concentration of suspended solids in Green Bay and central Lake Michigan, researchers have reported on the ability of the TM to resolve differences in these parameters. More recently, Khorram and others (1991) and Baban (1993, 1997) reported successful correlation of lake chlorophyll concentration and Secchi disk transparency with TM data using the same methods and TM models as this study.

The most important difference between these studies and the current one is the extremely low concentrations of phytoplankton chlorophyll typically found in Massachusetts lakes. Chlorophyll concentrations in the study lakes ranged from 0.5 to $84.5 \mu \mathrm{g} / \mathrm{L}$. However, the mean chlorophyll concentration was only $6.0 \mu \mathrm{g} / \mathrm{L}$ and the median concentration was $3.1 \mu \mathrm{g} / \mathrm{L}$. Median chlorophyll concentrations in lakes studied by Lillesand and others (1983) generally were much higher, often ranging from 30 to more than $100 \mu \mathrm{g} / \mathrm{L}$. Values of that magnitude were observed in fewer than 5 of the 97 lakes included in this study. In addition, color of the study lakes ranged from less than 1 to 547 PCU, with a mean of 91 and a median of 49 PCU. The wide variation in color may have introduced 


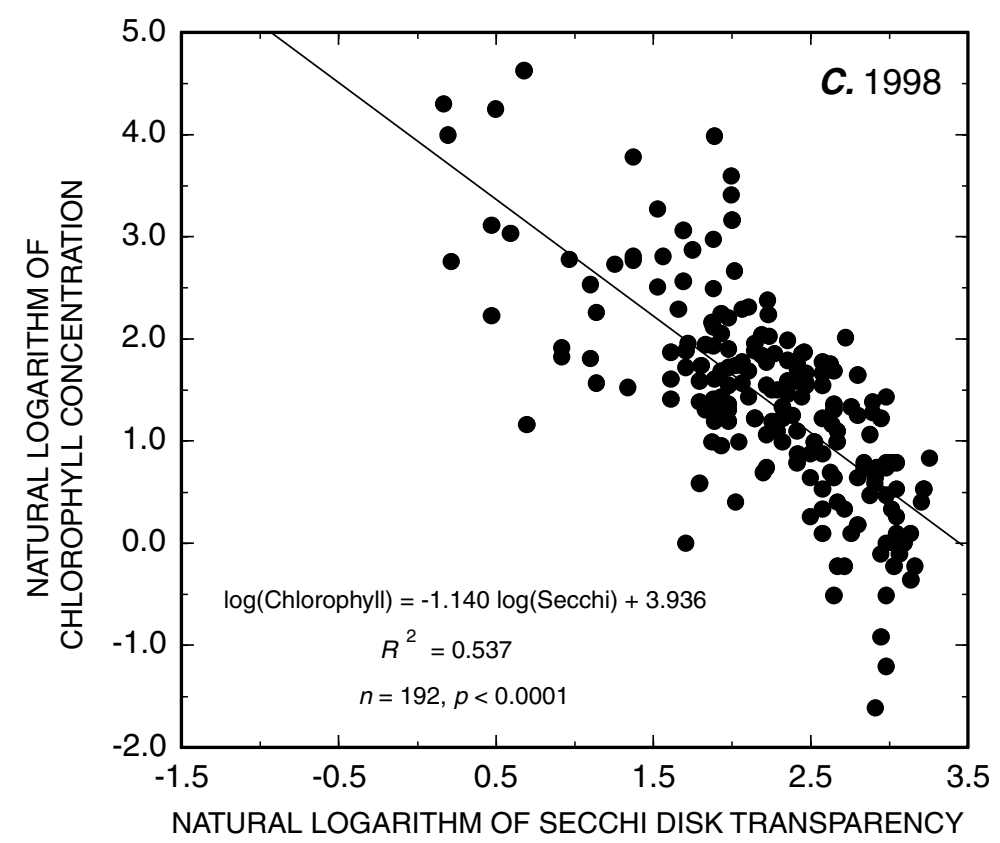

Figure 4. Relations between Secchi disk transparency and phytoplankton-chlorophyll concentration in Massachusetts lakes in (A) 1996; (B) 1997; and (C) 1998-Continued. additional variability into the relations between chlorophyll concentration, Secchi disk transparency, and the TM data. In any case, it appears that eutrophication of Massachusetts lakes frequently is manifested more by proliferation of macrophytes than it is by growth of phytoplankton.

\section{Lake Color and Dissolved Organic Carbon Concentration}

Analysis of color and dissolved organic carbon (DOC) concentrations in water samples collected by USGS field teams in 1996-98 indicated that color in Massachusetts lakes largely is due to DOC. The relation, shown in figure 5 , was highly significant with $R^{2}=0.914$. Samples collected by volunteers produced such variable results that no attempt was made to correlate them with TM data.

Table 5. Thematic mapper spectral bands and combinations of bands used as models to test for correlations with water-quality and trophic-state data for Massachusetts lakes

[TM, Thematic Mapper; TM1, TM band 1; TM2, TM band 2; TM3, TM band 3; TM4, TM band 4]

\begin{tabular}{|c|c|c|c|}
\hline TM1 & $(\mathrm{TM} 4)^{2}$ & $\frac{\mathrm{TM} 2}{\mathrm{TM} 3}$ & $\frac{\mathrm{TM} 4-\mathrm{TM} 3}{\mathrm{TM} 4+\mathrm{TM}}$ \\
\hline TM2 & $\ln (\mathrm{TM} 1)$ & $\ln \left(\frac{\mathrm{TM} 1}{\mathrm{TM} 2}\right)$ & $\frac{\mathrm{TM} 2-\mathrm{TM} 1}{\mathrm{TM} 2+\mathrm{TM} 1}$ \\
\hline TM3 & $\ln (\mathrm{TM} 2)$ & $\ln \left(\frac{\mathrm{TM} 1}{\mathrm{TM} 3}\right)$ & $\frac{\mathrm{TM} 2-\mathrm{TM} 3}{\mathrm{TM} 2+\mathrm{TM}}$ \\
\hline TM4 & $\ln (\mathrm{TM} 3)$ & $\ln \left(\frac{\mathrm{TM} 2}{\mathrm{TM} 3}\right)$ & $\ln \left(\frac{\mathrm{TM} 4-\mathrm{TM} 3}{\mathrm{TM} 4+\mathrm{TM} 3}\right)$ \\
\hline$(\mathrm{TM} 1)^{2}$ & $\ln (\mathrm{TM} 4)$ & $\frac{\mathrm{TM} 1+\mathrm{TM} 2}{2}$ & $\ln \left(\frac{\mathrm{TM} 2-\mathrm{TM} 1}{\mathrm{TM} 2+\mathrm{TM} 1}\right)$ \\
\hline$(\mathrm{TM} 2)^{2}$ & $\frac{\mathrm{TM} 1}{\mathrm{TM} 2}$ & $\frac{\mathrm{TM} 1+\mathrm{TM} 3}{2}$ & $\ln \left(\frac{\mathrm{TM} 2-\mathrm{TM} 3}{\mathrm{TM} 2+\mathrm{TM} 3}\right)$ \\
\hline$(\mathrm{TM} 3)^{2}$ & $\frac{\mathrm{TM} 1}{\mathrm{TM} 3}$ & $\frac{\mathrm{TM} 2+\mathrm{TM} 3}{2}$ & TM2 - TM3 \\
\hline
\end{tabular}




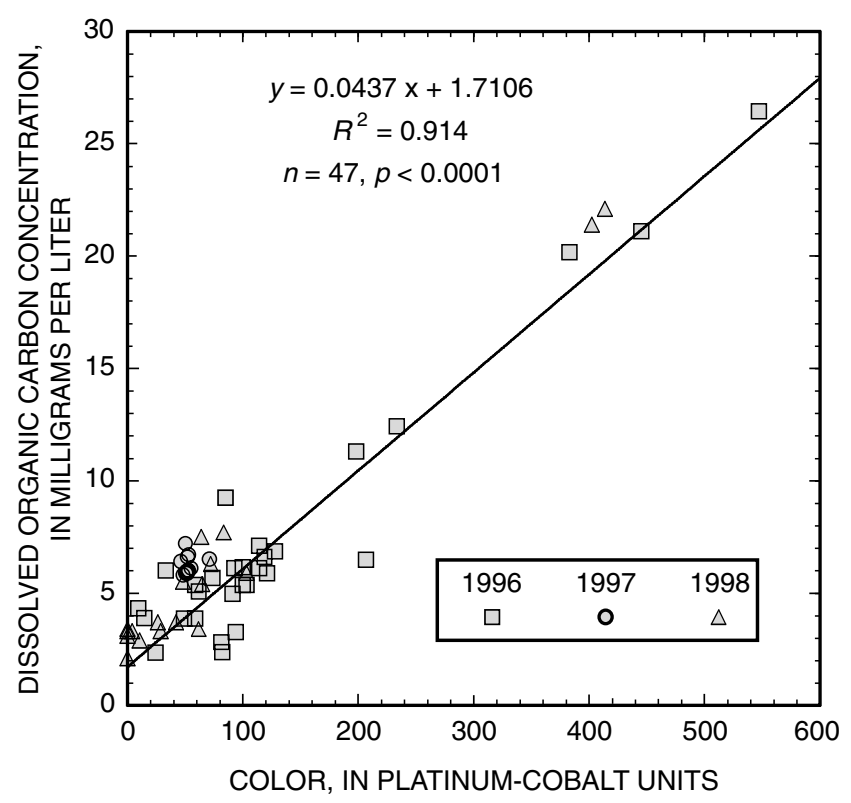

Figure 5. Relations between color and dissolved organic carbon concentration in Massachusetts lakes.

\section{THEMATIC MAPPER-BASED ASSESSMENT OF MACROPHYTE DISTRIBUTIONS}

A method was developed for mapping distributions of macrophytes in lakes, ponds, and reservoirs using TM images processed with a geographic information system (GIS). The TM-based mapping procedure consists of manually mapping the distributions of aquatic macrophyte beds in 10 to 15 representative lakes and relating the digitized field-generated maps to a set of TM images of the lakes. These relations are then used to assign pixel-brightness values in the TM images to one of four vegetation-cover classes: open water (no macrophytes), moderately covered (up to 50 percent) with floating or emergent macrophytes, densely covered (51-100 percent) with floating or emergent macrophytes, and covered to any extent with submerged macrophytes. These vegetation-cover class assignments can then be extended to any lake that is visible in the same TM scene.

\section{Field-Mapping of Macrophyte Distributions}

During 1996-98, distributions of floating, emergent, and submerged macrophytes were mapped in 44 Massachusetts lakes, ponds, and reservoirs by USGS and MADEM staff and by volunteers affiliated with the MassWWP. Twenty-four sets of maps, 12 produced in 1996 and 12 produced in 1997 from 19 of the lakes, were used to develop the TM-based mapping procedure. Excessive cloud cover during mid-to-late summer 1998 precluded the use of maps produced in that year. The 19 lakes (table 2) are primarily in the eastern half of Massachusetts and represent the range of lake types in that part of the State. Surface areas of the lakes ranged from 7 to 233 ha with a median surface area of 29 ha. Maximum depths ranged from 2 to $16 \mathrm{~m}$ with a median depth of $6 \mathrm{~m}$.

Field-mapping was conducted in late summer after the macrophytes had reached their maximum densities but before they began to senesce in early autumn. For each lake, a set of blank maps (field maps) was produced with a 1:24,000-scale (USGS Digital Line Graphs) outline of the lakeshore overlain by a lattice of cells representing the 30-by-30-meter spatial resolution of the TM images. These field maps were used by observers to record the macrophyte distributions.

Aquatic macrophyte beds were identified and mapped separately as floating, emergent, or submerged growth forms. Floating macrophytes, such as water lilies (Nuphar sp., Nymphaea sp.) and water shield (Brasenia schreberi), commonly are found from the shoreline inward to depths of between 1 and $3 \mathrm{~m}$. They may or may not be rooted in the sediments. Emergent macrophytes, such as cattails (Typha sp.), 
grasses (Phragmites sp.), rushes (Juncus sp.), sedges (Scirpus sp.), arrow arum (Peltandra virginica), and pickerelweed (Pontederia cordata), typically are rooted and have foliage that extends out of the water. Emergent macrophytes generally are found along the edges of lakes in shallow water rarely exceeding $1 \mathrm{~m}$ in depth. Submerged macrophytes, such as fanwort (Cabomba sp.), various pondweeds (Potamogeton sp., Najas sp.), coontail (Ceratophyllum sp.), watermilfoil (Myriophyllum sp.), and bladderwort (Utricularia sp.), may occur from the shoreline across the entire lake bottom, but rarely extend beyond a depth of about $10 \mathrm{~m}$ because of hydrostatic pressure and the limited penetration of underwater light.

Mapping of floating and emergent macrophytes consisted of moving slowly along the shoreline in a boat and recording the locations of the macrophyte beds on the field maps. The lattice of 30-by-30 m cells superimposed on the lakeshore outline provided a scale by which observers could judge distances from the shore and accurately mark locations of the beds. The maps also indicated the positions of major landmarks such as roads, dams, and tributary streams, which provided additional reference points for mapping.

Macrophyte density within the mapped beds was estimated by the observers as (1) open water, (2) sparse (greater than 0 but less than 25 percent cover), (3) moderate (greater than 25 percent but less than 50 percent cover), (4) dense (greater than 50 percent but less than 75 percent cover), (5) very dense (greater than 75 percent cover but less than 100 percent cover), or (6) complete (100 percent cover). Visual comparison of duplicate maps prepared at the same time by independent observers for three lakes in 1998 indicated that these density ranges were large enough to subsume minor differences or errors in the observers' density estimates.

Mapping of submerged macrophytes consisted of establishing multiple transects extending from shore to shore across the lakes. Transects usually were spaced about $120 \mathrm{~m}$ apart, except in the largest lakes, where they were spaced about $200 \mathrm{~m}$ apart. Landmarks represented on the maps were used as control points in locating the transects. Sampling points were then located at intervals of 60 to $120 \mathrm{~m}$ along each transect, either by direct measurement with a range finder or by estimating the distance and marking the position relative to the 30-by-30-meter cells printed on the map. At each sampling point, a weighted two-sided rake, $0.46 \mathrm{~m}$ in length, was lowered on a line and dragged along the lake bottom for a distance of about $2 \mathrm{~m}$. The amount of plant material retrieved on the rake relative to that retrieved in an area with visible submerged vegetation was used to estimate the areal coverage of submerged macrophytes at that point. A submerged-vegetation distribution map was then produced for each lake based on the estimated areal coverages.

\section{Digitization and Processing of Field Maps}

The hand-drawn field maps of macrophyte distributions were digitized by scoring the centroid of each 30-by-30-meter cell as one of the six ranges of cover values, based on the mapped locations of the macrophyte beds. The scores for each map were then used to populate the cells of a raster grid corresponding to the lattice originally plotted on the map. The resulting grids were vectorized, clipped into the lake shoreline boundaries, and merged into a single data layer for each vegetation-cover type. The three data layers were then merged into a single data layer, maintaining the cover values for each vegetation-cover type.

Because the emergent vegetation was always close to the lake shorelines, and because it represented only a small part of the total covered area of most lakes, the cover values for floating and emergent vegetation types were combined into a single surface vegetation type. Also, the six original vegetationcover classes were reduced to four summary classes: 
(1) open water, (2) 1-50 percent floating-andemergent-vegetation cover, (3) 51-100 percent floating-and-emergent-vegetation cover, and (4) submerged vegetation at all densities (when not hidden by surface vegetation), when preliminary analyses indicated a potential bias in favor of open water. The result of combining vegetation-cover classes with small areal distributions into larger summary cover classes was to reduce the influence of the large areal extent of open water in many of the field maps on the final assignments of the TM pixel-brightness values.

\section{Image Interpretation}

Data in the TM scenes were processed into ARC/INFO by creating raster grids for TM2, TM3, and TM4 DNs. Grids for individual lakes were generated from these three TM-scene raster grids and rectified to the lake grids. The individual lake grids were then vectorized, clipped into the lakeshore boundaries, and merged into a single data layer for each of the three TM bands. The three data layers were then merged into a single data layer maintaining the DNs for each TM band. The effects of atmospheric haze were removed from the data for TM2 and TM3 by subtracting the smallest DNs for each wave band from all the brightness values for that wave band in the vector grid (Wilkie and Finn, 1996).

For each 30-by-30-meter cell in the data layer, a normalized difference vegetation index (NDVI; Lillesand and Kiefer, 1994) was calculated using the hazecorrected DNs for TM3 and TM4 as follows:

$$
N D V I=\frac{T M 4-T M 3}{T M 4+T M 3}
$$

This data layer was merged with the data layer containing the four vegetation-cover classes. Inconsistencies in alignment of the 30-by-30-meter cells in the two data layers were corrected by bringing the combined data layer back into raster grid mode and using coordinates for each lake derived from the original TM images to rectify the cells in the vegetation-cover class data layer. The combined data layer was vectorized and 30-by-30-meter cells falling entirely within lakeshore boundaries were given a new attribute that differentiated them from the smaller cells that intersected the shorelines. Cells associated with islands in the lakes were similarly differentiated.

Cells that did not intersect with lake shorelines were grouped according to their NDVI values. For each NDVI value, the total areas were determined for the two surface vegetation-cover classes (1-50 percent and 51-100 percent floating and emergent) and for a hybrid vegetation-cover class consisting of open water and submerged vegetation. The vegetation-cover class comprising the largest total area of the three was then assigned to that NDVI value. In this way, each NDVI value in the dataset was associated with one of the three surface-vegetation cover classes or with open water. These associations were then used to assign vegetations cover classes to cells that intersected the lake shorelines.

The vegetation-cover class assignments for each cell were then examined to determine if any should be changed based on the NDVI values of adjacent cells. If a given NDVI value predominated in the eight-cell neighborhood surrounding a cell, then that NDVI value was added to the cell as an alternative value. Next, all cells with that combination of NDVI value and alternative value were selected and assigned the vegetationcover class most frequently associated with the combination. In this way, some inconsistent assignments arising from the limited spatial resolution of the TM data were removed.

To determine areas of submerged vegetation, all cells that were not assigned a surface-vegetation cover class in the NDVI analysis were isolated, and a ratio index was calculated by dividing the haze-corrected DNs for TM2 by those for TM3. The steps performed to assign NDVI values were then repeated on these isolated cells, the one difference being that the cells digitized as submerged vegetation were maintained and included as an option for assignment. 


\section{Observed Versus Predicted Macrophyte Distributions}

Satellite images from July 22, 1996, and August 26, 1997, were used, together with mapped distributions of 1996 and 1997 aquatic-vegetation cover in 19 study lakes, to develop predictive models relating the satellite data to the observed macrophyte distributions. Relations developed for the 1996 data were used to predict distributions in the original 1996 lakes, and relations developed for the 1997 data were used to predict distributions in the original 1997 lakes. Finally, the relations developed for the 1997 data were tested on the 1996 satellite scene and the predicted results compared with observed 1996 macrophyte distributions.

\section{Predictions Based on 1996 Interpretations}

Figure 6 shows the relations between observed (field mapped in summer 1996) and predicted (interpreted from 1996 Thematic Mapper data) aquaticmacrophyte cover areas in twelve 1996 study lakes for each of the four vegetation-cover classes. For open water, the root-mean-squared-error (RMSE) of the prediction was 3.6 ha for observed cover areas ranging from 0 to 39.7 ha. Predicted open-water cover areas tended to be smaller than observed openwater cover areas. This result can been observed in figure 7, which shows maps of observed and predicted aquatic-vegetation cover for Whitehall Reservoir, in Hopkinton, Mass. Agreement between observed and predicted cover areas for the other three vegetationcover classes was very good, with RMSE ranging from 1.3 ha for 51-100 percent floating-and-emergent-vegetation cover to 5.7 ha for submerged vegetation cover (fig. 6).

\section{Predictions Based on 1997 Interpretations}

The TM-based maps developed from the 1997 data set did not match the observed 1997 maps as closely as did those developed from the 1996 data set. The TM-based mapping procedure predicted larger amounts of open-water cover area and smaller amounts of submerged vegetation cover area than were observed (fig. 8), although the RMSE values were similar to those exhibited by the 1996 relations ( 6.3 ha for openwater cover and 5.3 ha for submerged vegetation cover). Lakes in the 1997 data set tended to have larger observed open-water cover areas than those in the 1996 data set (fig. 9). The median observed open-water cover area was 11.9 ha in the 1997 data set and 8.2 ha in the 1996 data set. Similarly, observed cover areas for submerged vegetation were much smaller in the 1997 data set (median $=0.7 \mathrm{ha}$ ) than they were in the 1996 data set $($ median $=5.8 \mathrm{ha})$.

Agreement between observed and predicted cover areas was better for the two floating-andemergent-vegetation cover classes (the RMSE was 2.5 ha for the 1-50 percent floating-and-emergent cover class and 1.1 ha for the 51-100 percent floatingand-emergent cover class) than it was for the open water and submerged-vegetation cover classes (fig. 8). Because most of the observed areas for these classes were very small (1.0 to $6.0 \mathrm{ha}$ ), however, the errors are significant.

\section{Predictions Based on 1997 Interpretations}

An attempt to predict vegetation-cover class areas in the 1996 study lakes based on interpretations developed from the 1997 data set was unsuccessful. Large areas of submerged or floating and emergent vegetation were interpreted as open water for many lakes. Consequently, predicted cover areas for submerged vegetation and the 1-50 percent floating-andemergent-vegetation class were smaller than the corresponding observed cover areas and had correspondingly large RMSE values [27.7 and 11.4 ha, respectively (fig. 10)]. The only exceptions were the areas predicted for the 51-100 percent floating-andemergent-vegetation cover class, which produced a RMSE of 1.1 ha over observed (1996) cover values ranging from 0 to $26.8 \mathrm{ha}$. The large discrepancy in predicted versus observed areas of submerged vegetation can be seen in figure 11, which maps predicted and observed aquatic vegetation cover for East Brimfield Reservoir in Brimfield and Sturbridge, Mass. 


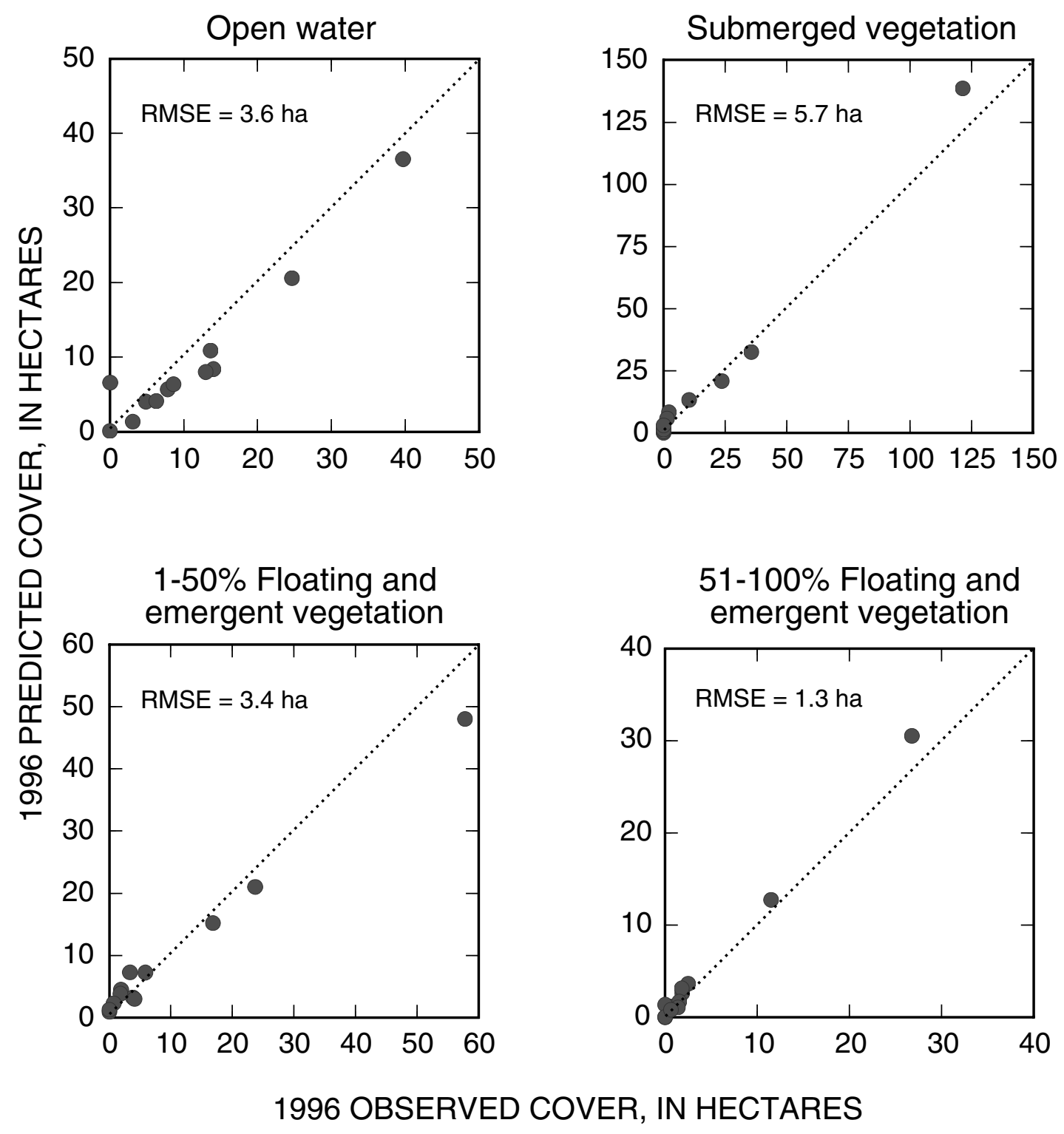

Figure 6. Observed (field-mapped in summer 1996) and predicted (interpreted from July 1996 Thematic Mapper data) areal coverages of four aquatic macrophyte cover classes coverages in 12 Massachusetts lakes. 


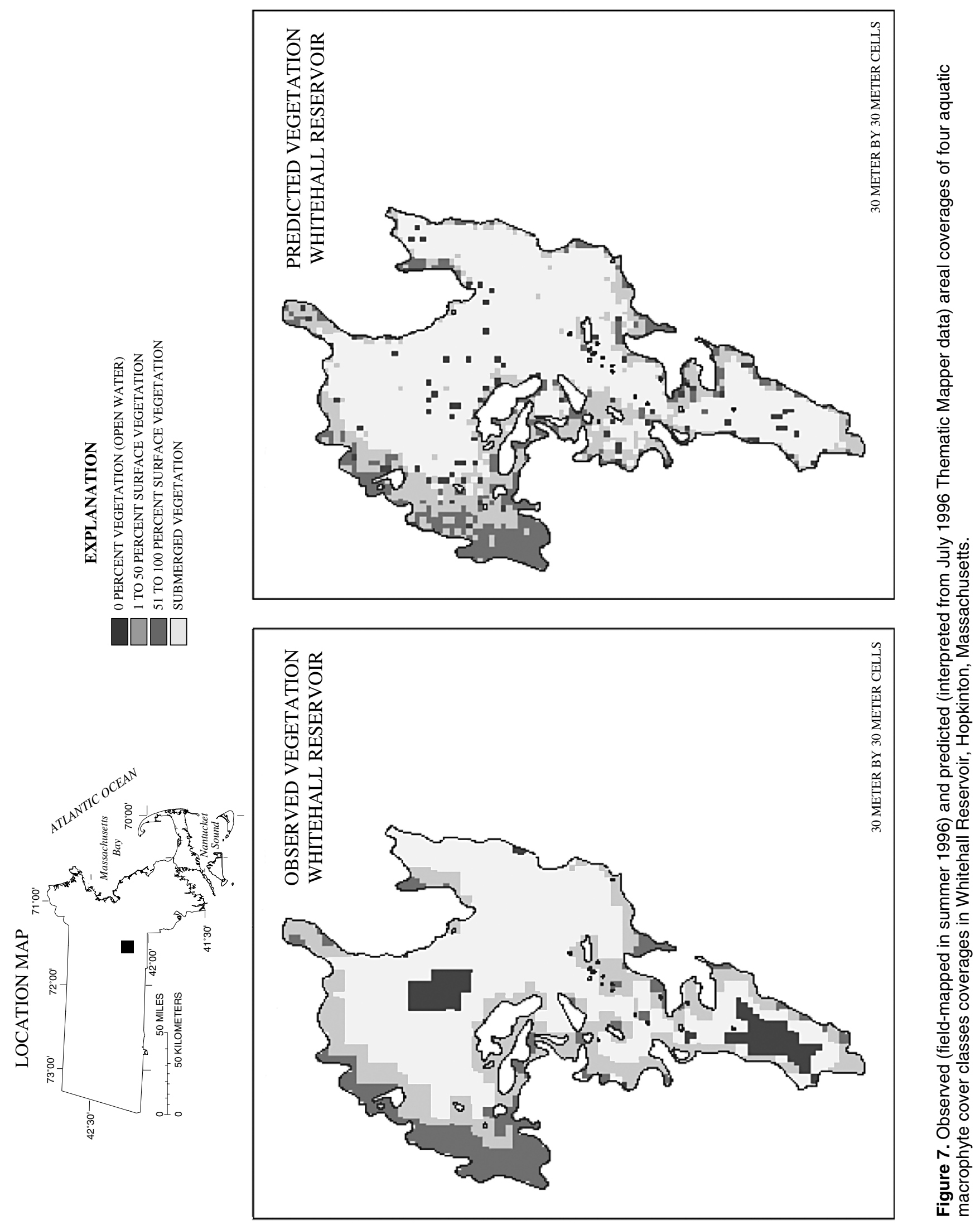



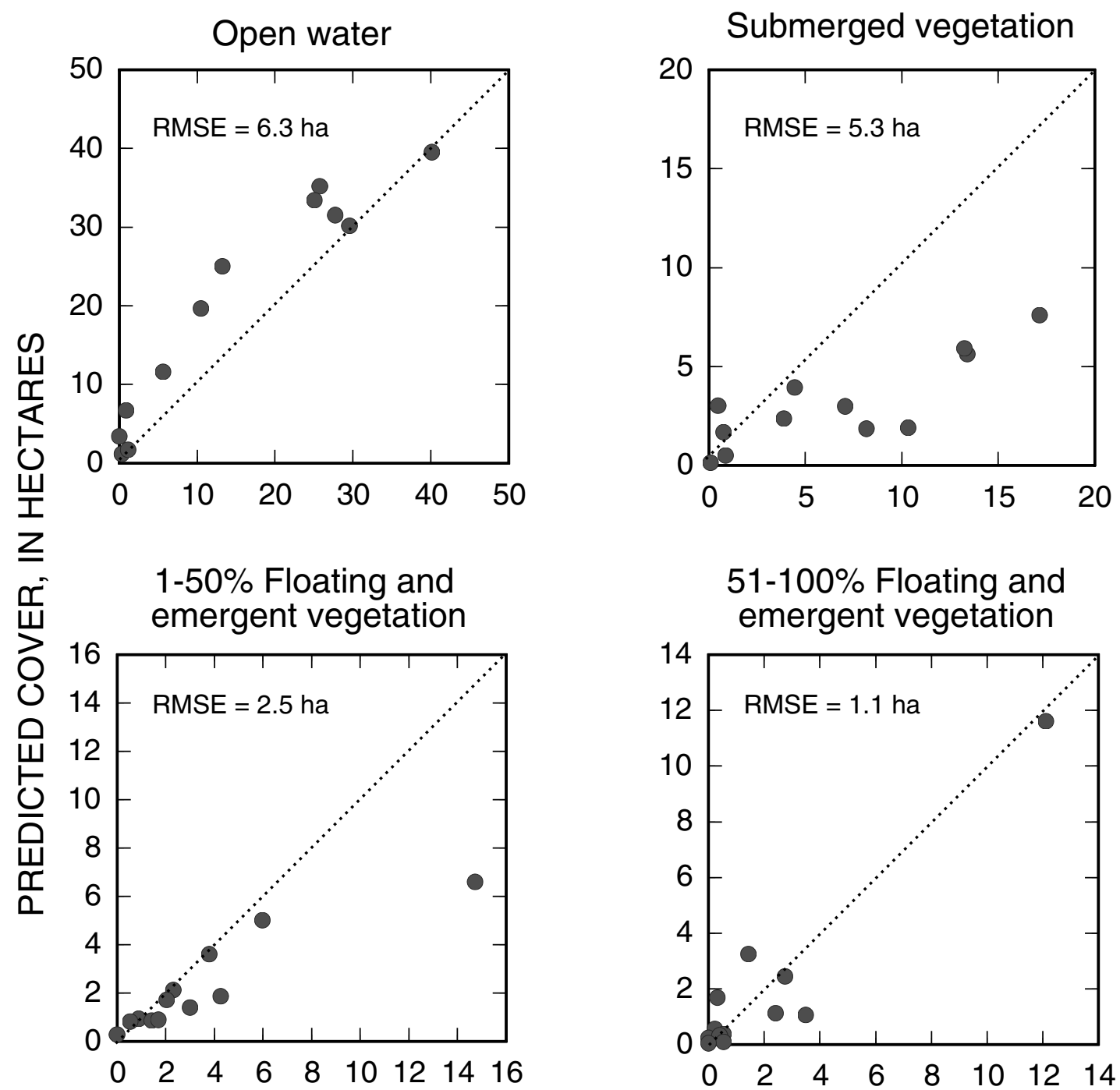

OBSERVED COVER, IN HECTARES

Figure 8. Observed (field-mapped in summer 1997) and predicted (interpreted from August 1997 Thematic Mapper data) areal coverages of four aquatic macrophyte cover classes coverages in 12 Massachusetts lakes. 


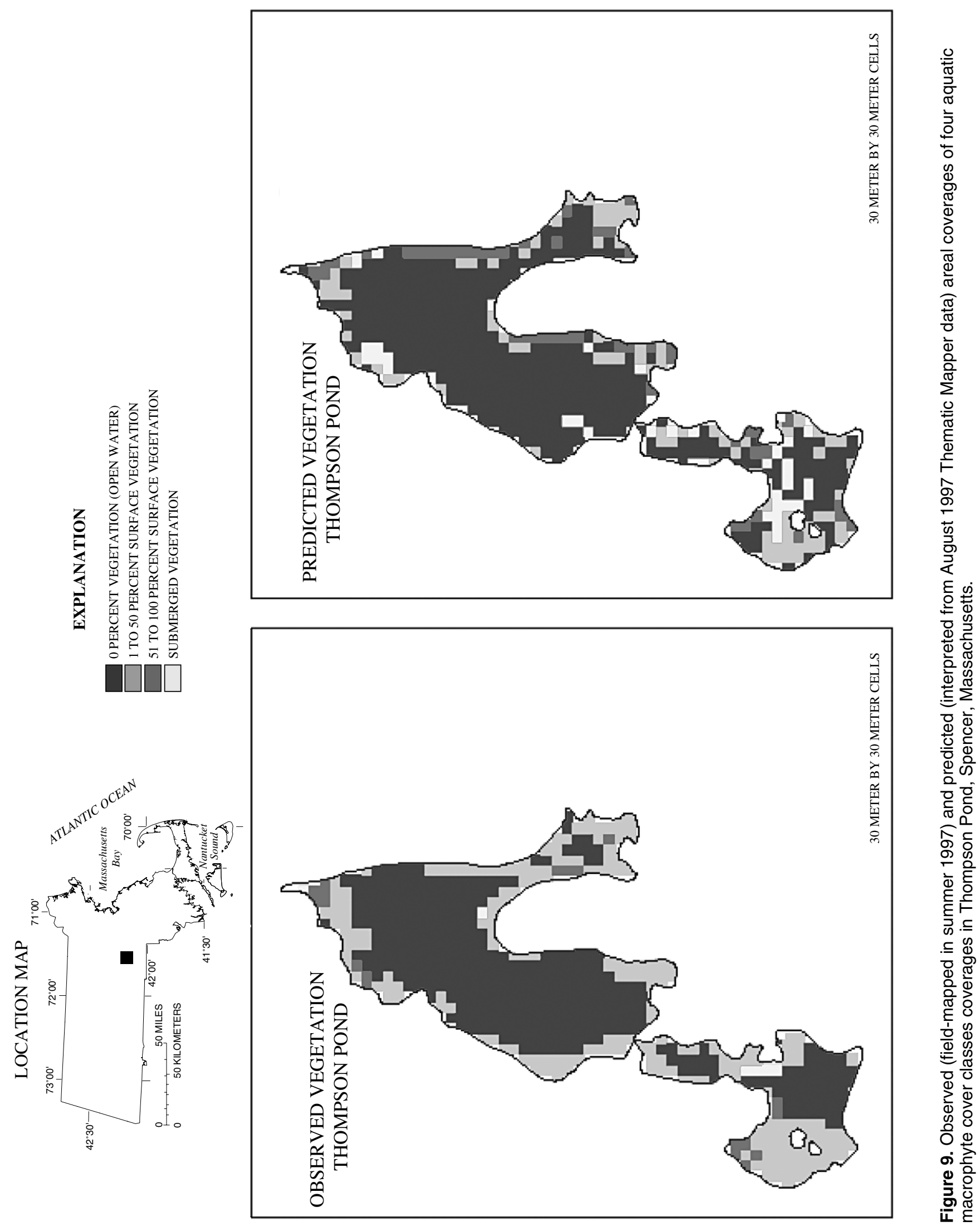




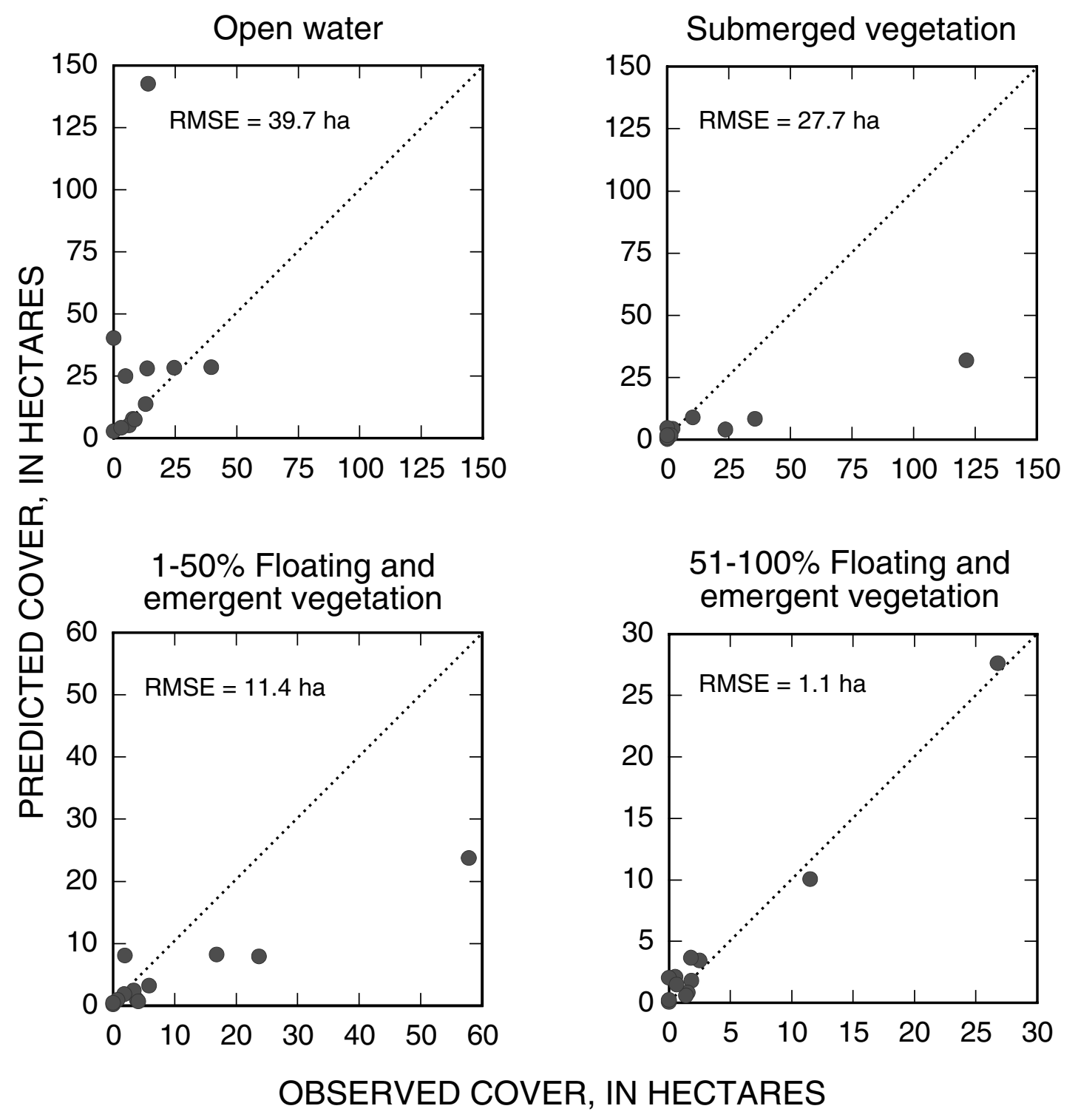

Figure 10. Observed (field-mapped in summer 1996) and predicted (interpreted from August 1997 Thematic Mapper data) areal coverages of four aquatic macrophyte cover classes coverages in 12 Massachusetts lakes. 


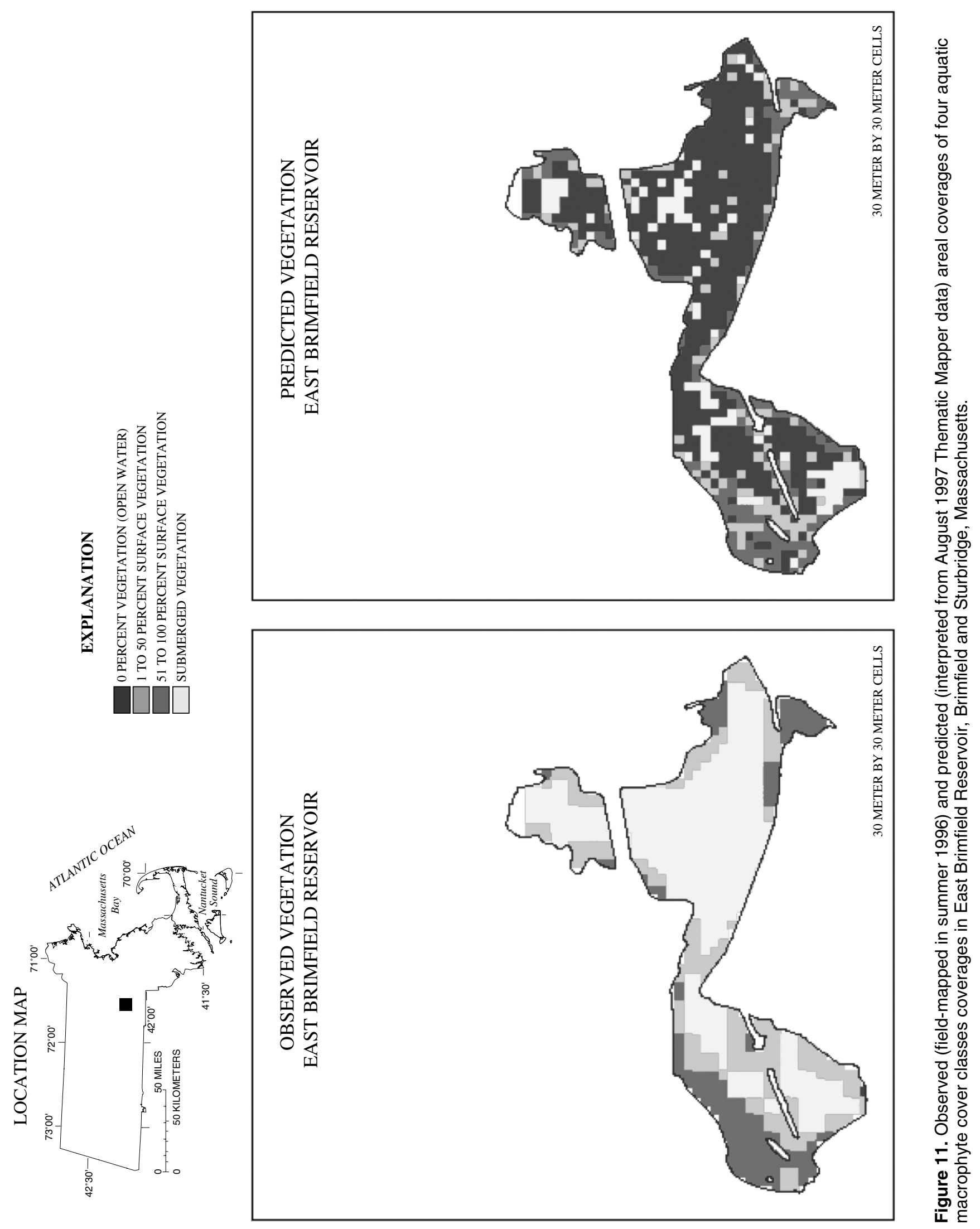




\section{SUMMARY AND CONCLUSIONS}

During the spring and summer of 1996, 1997, and 1998, measurements of phytoplankton- chlorophyll concentration, Secchi disk transparency, and color were made at 97 Massachusetts lakes within 24 hours of Landsat Thematic Mapper (TM) imaging of the lakes in an effort to use the TM imagery to assess lake-water quality. Spatial distribution of floating, emergent, and submerged macrophytes were mapped in 49 of the lakes at least once during the three-year period. The maps were digitized and used to assign pixels in the TM images to one of four vegetation cover classes-open water, 1-50 percent floating-andemergent-vegetation cover, 51-100 percent floatingand-emergent-vegetation cover, and submerged vegetation at any density. Concurrent data collection and sampling by USGS and trained volunteer field teams resulted in similar chlorophyll determinations, Secchi disk readings, and temperature measurements, but color determinations were highly variable, possibly due to contamination of sample bottles issued to the volunteers.

Attempts to develop predictive relations between phytoplankton-chlorophyll concentration, Secchi disk transparency, lake color, dissolved oxygen concentration (DOC), and various combinations of TM band 1, 2, 3, and 4 digital numbers (DNs) were unsuccessful. The poor relations were primarily the result of the extremely low chlorophyll concentrations (median = $3.1 \mu \mathrm{g} / \mathrm{L}$ ) in the lakes studied, and also because of the highly variable DOC concentrations as indicated by color values ranging from less than 1 to 547 platinum-cobalt units (PCU).

Predictive relations were developed between Secchi disk transparency and phytoplanktonchlorophyll concentration and between color and DOC concentration. Phytoplankton-chlorophyll concentration was inversely correlated with Secchi disk transparency during all three sampling periods. The regression equations for the relations in 1996 and 1997 were similar and showed that 62 to 67 percent of the variability in chlorophyll concentration could be explained by the Secchi disk transparency. Analysis of color and DOC concentrations in water samples collected by USGS field teams in 1996-98 indicated that most of the color in Massachusetts lakes is due to DOC.

Areas of open-water, submerged vegetation, and two surface-vegetation-cover classes predicted from TM images acquired in the summer of 1996 closely matched the areas observed in a set of field observations. Agreement between observed and predicted 1996 submerged-macrophyte cover areas was at least as good as the 56- to 70-percent accuracy reported for mapping studies using visual interpretations of aerial photographs (Schloesser and others, 1987); however, the same analysis applied to a set of data acquired in the summer of 1997 resulted in somewhat less reliable predictions, and an attempt to predict 1996 vegetation cover areas using the relations developed in the 1997 analysis was unsuccessful.

Differences in the predictive power of the two data sets appear to stem from differences in the relative sizes of the vegetation-cover areas used in the initial calibration of the NDVI values. The ranges of observed areas of the four vegetation-cover classes were similar in the 1996 data set. By contrast, open water predominated in lakes forming the 1997 data set, and the other vegetation-cover classes had much smaller and more variable ranges. Both the field-mapping and the TMimaging processes are subject to error. Locations of the macrophyte beds indicated on the field maps cannot be exact, and the TM images are limited by the 30-by-30meter ground resolution of the instrument. Under these conditions, a preponderance of one type of vegetation cover class in the calibration data set is likely to result in more assignments of NDVI values to that cover class, simply because locational errors involving that cover class will tend to occur more frequently. It is also possible that the failure of the method to accurately predict the 1996 macrophyte distributions based on interpretations of 1997 data was due in part to this problem.

Ideally, the method should be applied to a set of mapped lakes and then tested on a second set not used in the initial calibration. This was not possible given the limited number of field maps available in the two data sets and the need for equal areal representation of 
vegetation-cover classes. By careful selection of the initial set of lakes to ensure adequate representation of vegetation cover, it may be possible to use fewer lakes in the calibration process without sacrificing predictive power. The calibration data set also could be improved by using a global-positioning system to accurately locate and map the aquatic macrophyte beds.

\section{REFERENCES CITED}

American Public Health Association, American Water Works Association, and Water Pollution Control Commission, 1995, Standard methods for the examination of water and wastewater (19th ed.): Washington, D.C., APHA, [variously paginated].

Baban, S.M.J., 1993, Detecting water quality parameters in the Norfolk Broads, U.K., using Landsat imagery: International Journal of Remote Sensing, vol. 14, no. 7, p. $1247-1267$.

1997, Environmental monitoring of estuaries; estimating and mapping various environmental indicators in Breydon Water Estuary, U.K., using Landsat TM imagery: Estuarine, Coastal, and Shelf Science, vol. 44, p. 589-598.

Canfield, D.E., Jr., Langland, K.A., Maceina, M.J., Haller, W.T., and Shireman, J.V., 1983, Trophic state classification of lakes with aquatic macrophytes: Canadian Journal of Fisheries and Aquatic Sciences, v. 40, p. $1713-1718$.

Fishman, M.J., and Friedman, L.C., eds., 1989, Methods for determination of inorganic substances in water and fluvial sediments: U.S. Geological Survey Techniques of Water-Resources Investigations, book 5, chap. A1, $545 \mathrm{p}$.

Goldman, C.R., and Horne, A.J., 1983, Limnology: New York, McGraw-Hill Book Co., 464 p.

Khorram, Siamak, Cheshire, Heather, Geraci, Alberto L., and LaRosa, Guido, 1991, Water quality mapping of Agusta Bay, Italy, from Landsat-TM data: International Journal of Remote Sensing, vol. 12, no. 4, p. 803-808.

Lathrop, R.G., Jr., and Lillesand, T.M., 1986, Use of Thematic Mapper data to assess water quality in Green Bay and central Lake Michigan: Photogrammetric Engineering and Remote Sensing, vol. 52, no. 5, p. $671-680$.
Lillesand, T.M., Johnson, W.L., Deuell, R.L., Lindstrom, O.M., and Meisner, D.E., 1983, Use of Landsat data to predict trophic state of Minnesota lakes: Photogrammetric Engineering and Remote Sensing, v. 49 , no. 2, p. 219-229.

Lillesand, T.M., and Kiefer, R.W., 1994, Remote sensing and image interpretation (3rd ed.): New York, John Wiley and Sons, Inc., $750 \mathrm{p}$.

Massachusetts Water Resources Commission, 1994, Policy on lake and pond management: Boston, Massachusetts Water Resources Commission, Division of Water Resources, $5 \mathrm{p}$.

Raitala, J.T., 1986, Satellite data in aquatic research-Some ideas for future studies: Symposium on Remote Sensing for Resources Development and Environmental Management, Enschede, August, 1986, p. 755-758.

Scarpace, F.L., Holmquist, K.W., and Fisher, L.T., 1979, Landsat analysis of lake quality: Photogrammetric Engineering and Remote Sensing, v. 45, no. 5, p. 623633.

Schloesser, D.W., Manny, B.A., Brown, C.L., and Jaworski, E., 1987, Use of low-altitude aerial photography to identify submersed macrophytes, in Color Aerial Photography in the Plant Sciences and Related Fields: Ann Arbor, University of Michigan, Proceedings of the 10th Biennial Workshop, 1984, p. 19-28.

Shimoda, H., Etaya, M., Sakata, T., Goda, L., and Stelczer, K., 1986, Water quality monitoring of Lake Balaton using LANDSAT MSS data: Symposium on Remote Sensing for Resources Development and Environmental Management, Enschede, August, 1986, p. 765-770.

U.S. Environmental Protection Agency, 1995, The state of the New England environment, 1970-1995: Boston, Mass., U.S. Environmental Protection Agency-New England, Office of External Programs, $20 \mathrm{p}$.

Verdin, J.P., 1985, Monitoring water quality conditions in a large western reservoir with Landsat imagery: Photogrammetric Engineering and Remote Sensing, v. 51, p. 343-353.

Wilkie, D.S., and Finn, J.T., 1996, Remote sensing imagery for natural resources monitoring - A guide for first-time users: New York, Columbia University Press, 295 p.

Witzig, A.S., and Whitehurst, C.A., 1981, Current use and technology of LANDSAT MSS data for lake trophic classification: Water Resources Bulletin, vol. 17, no. 6, p. 962-970. 
Tables 6 and 7 


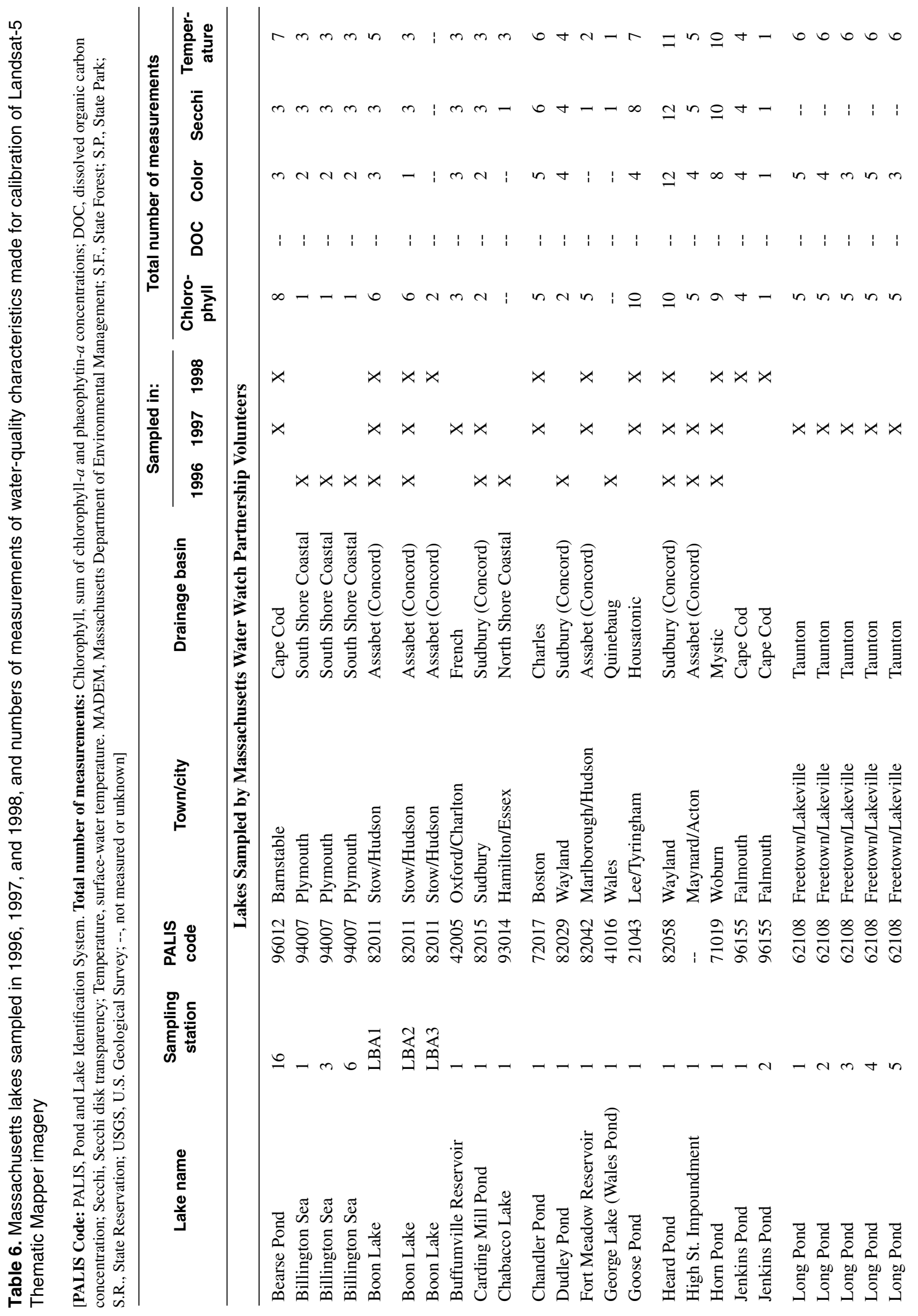




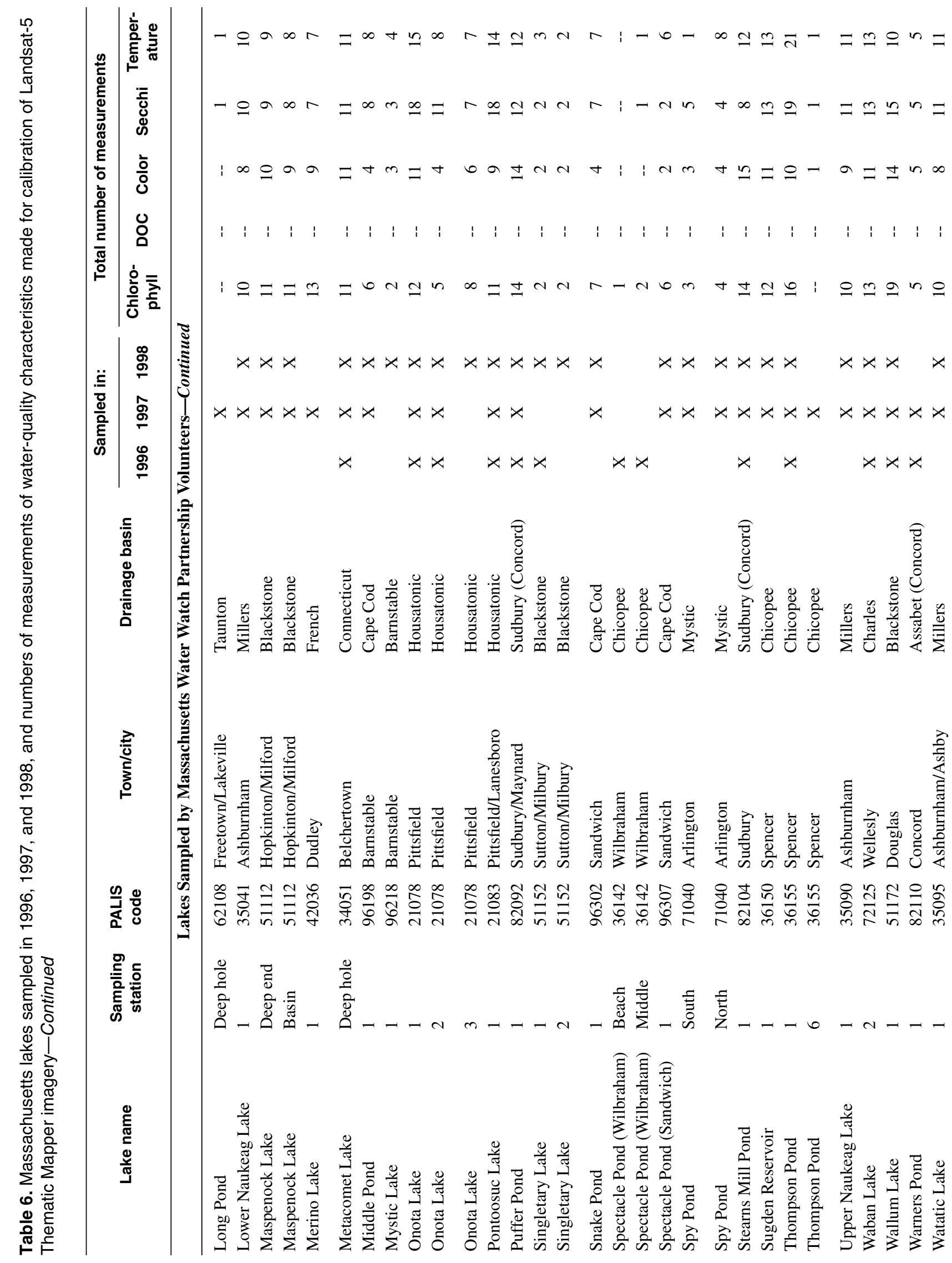




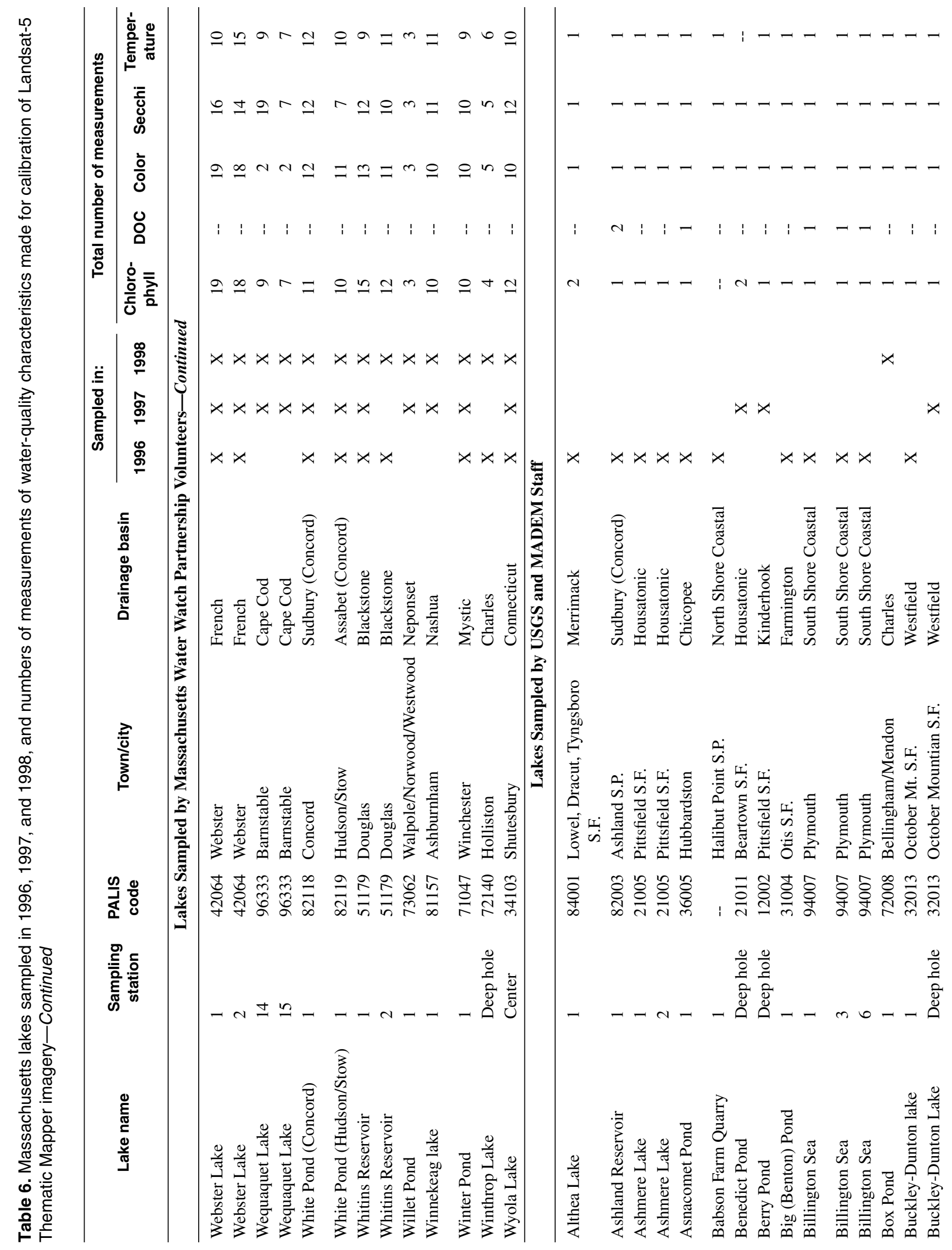




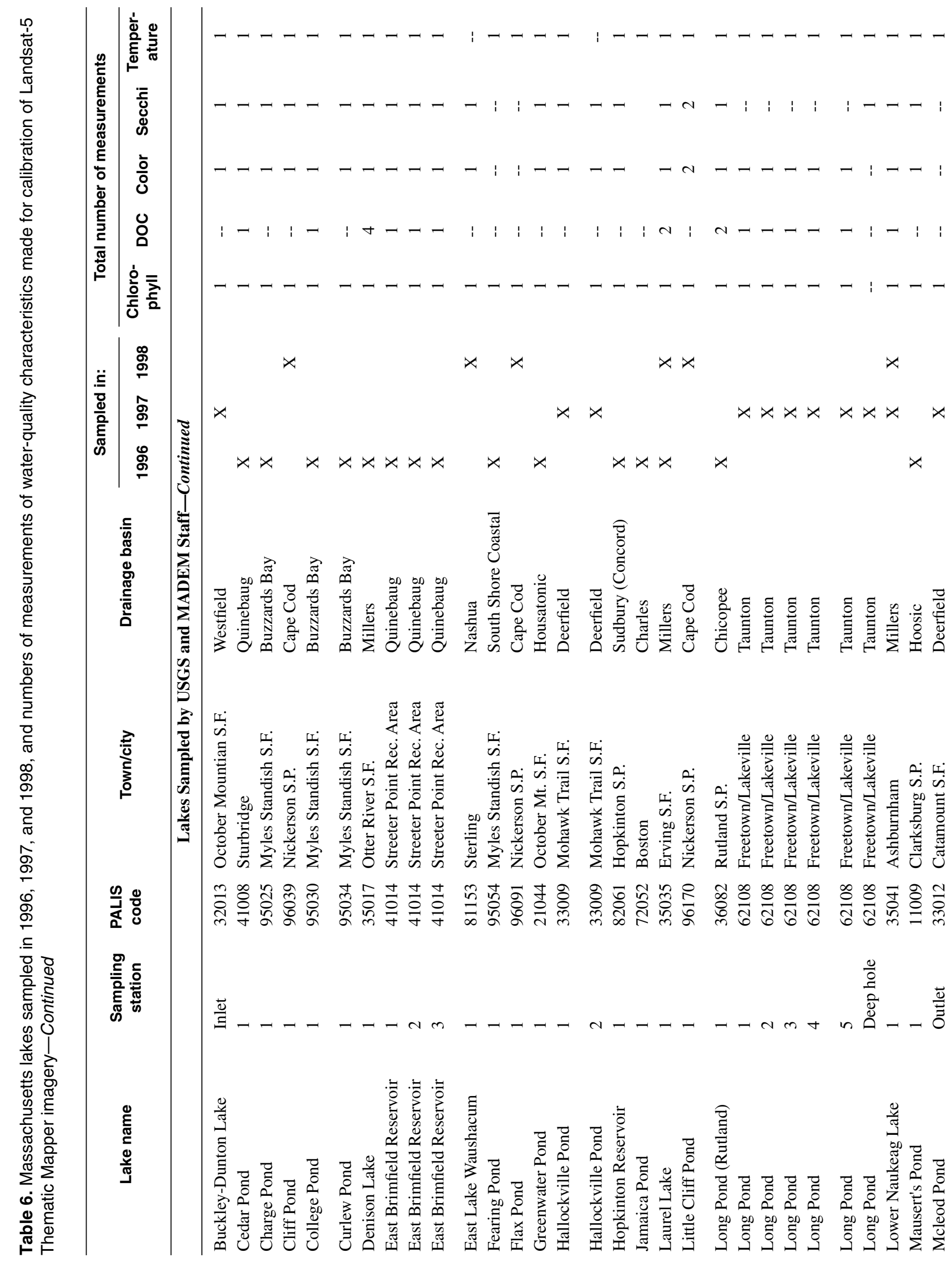




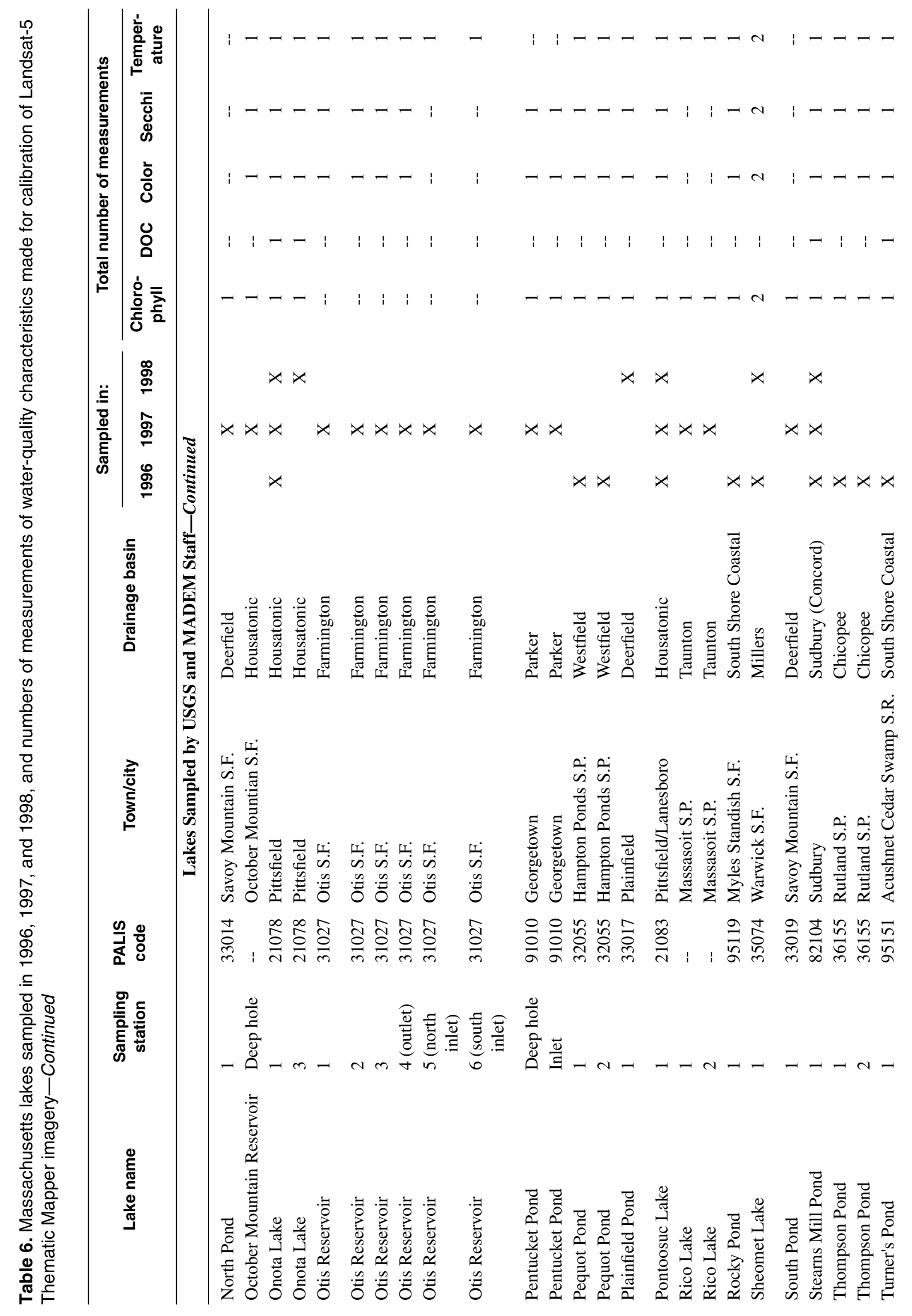




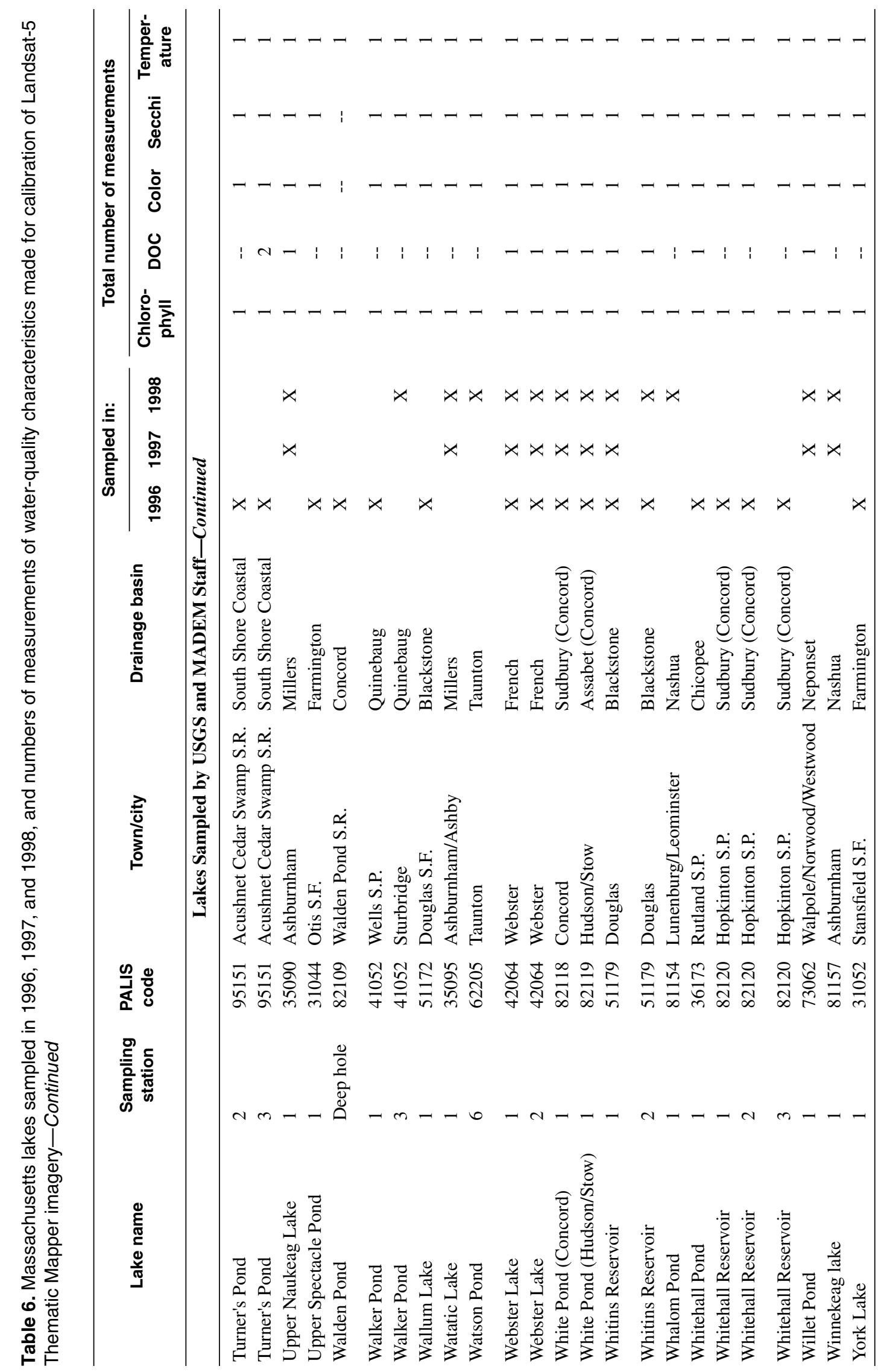




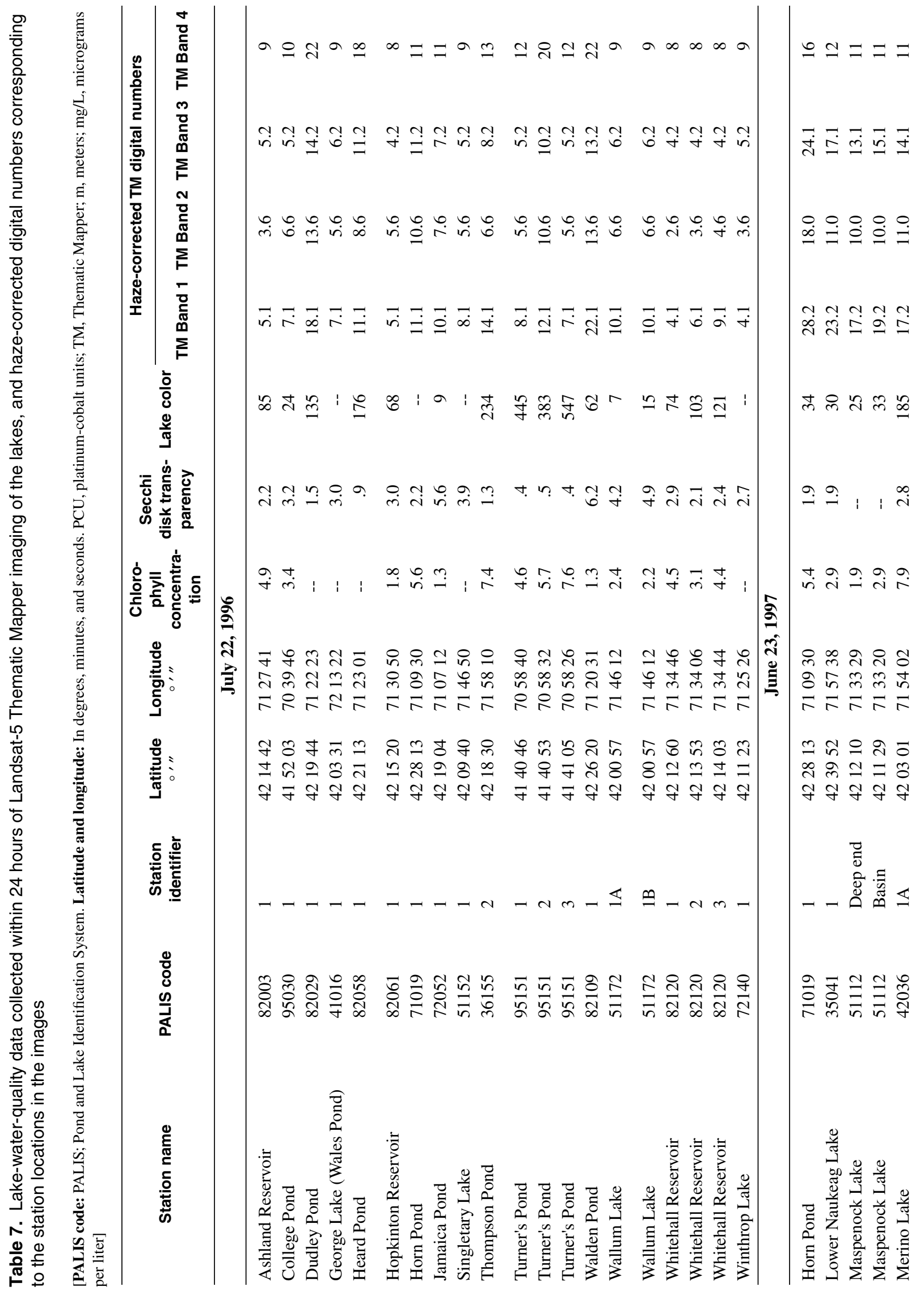




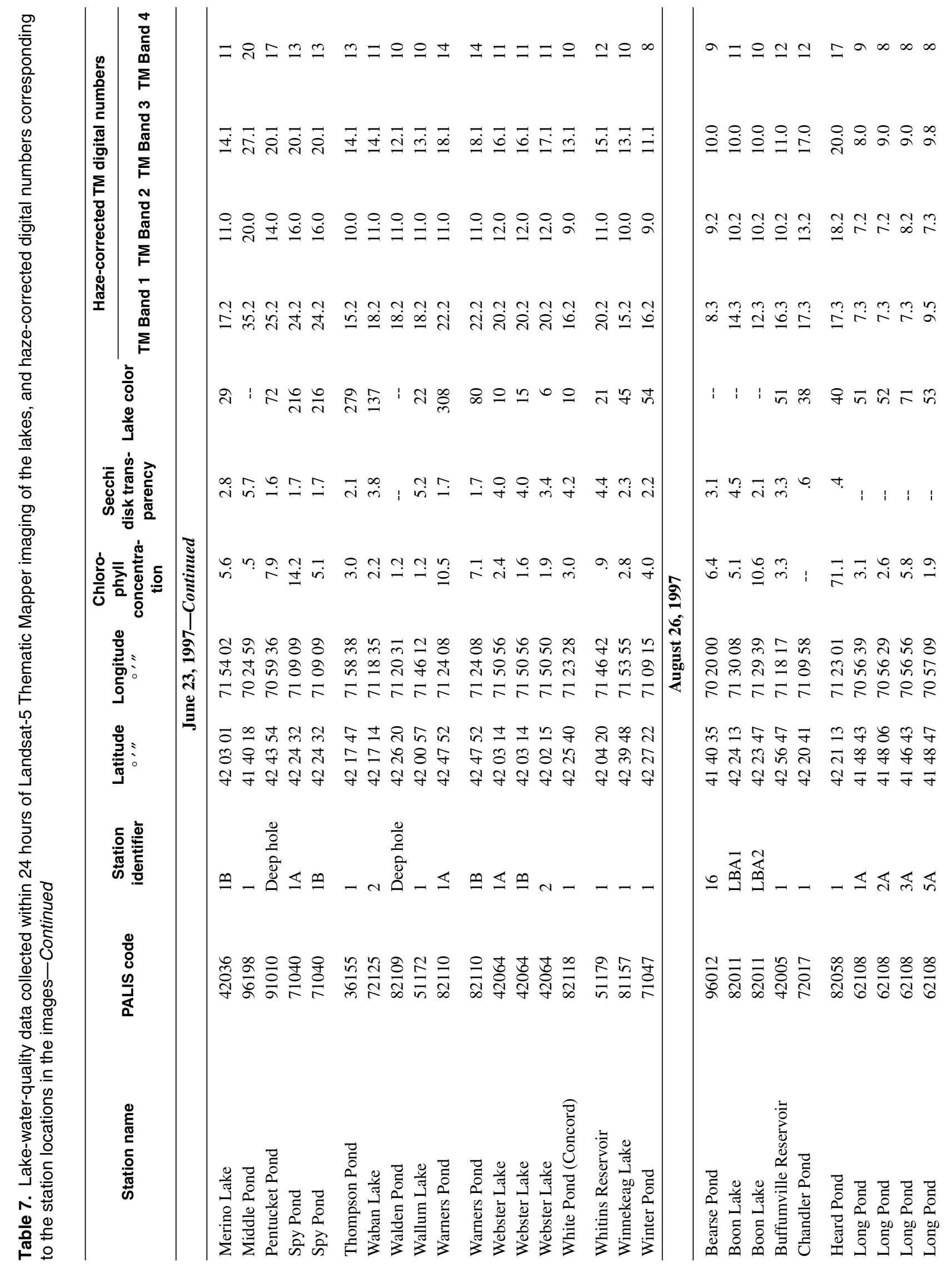




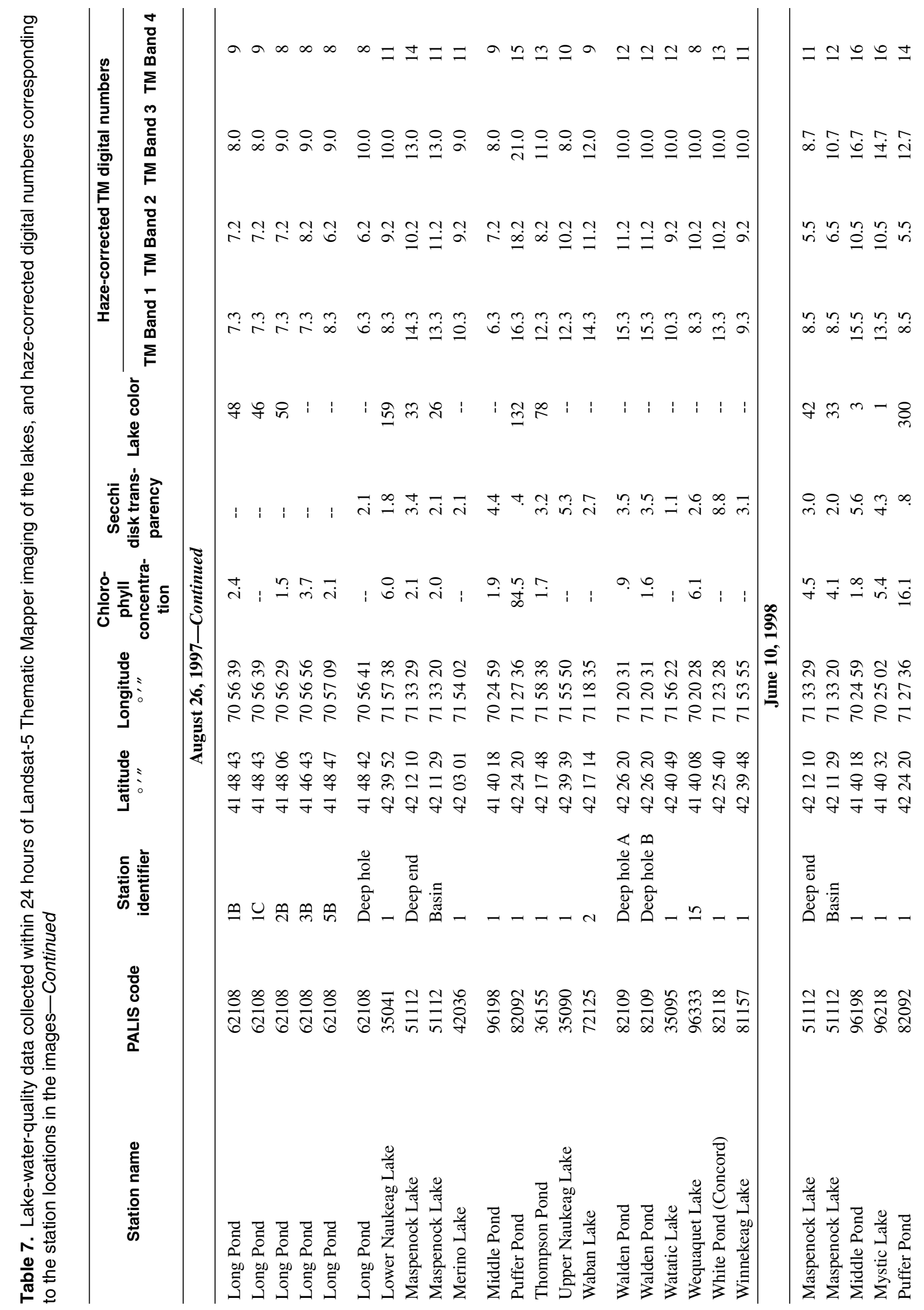




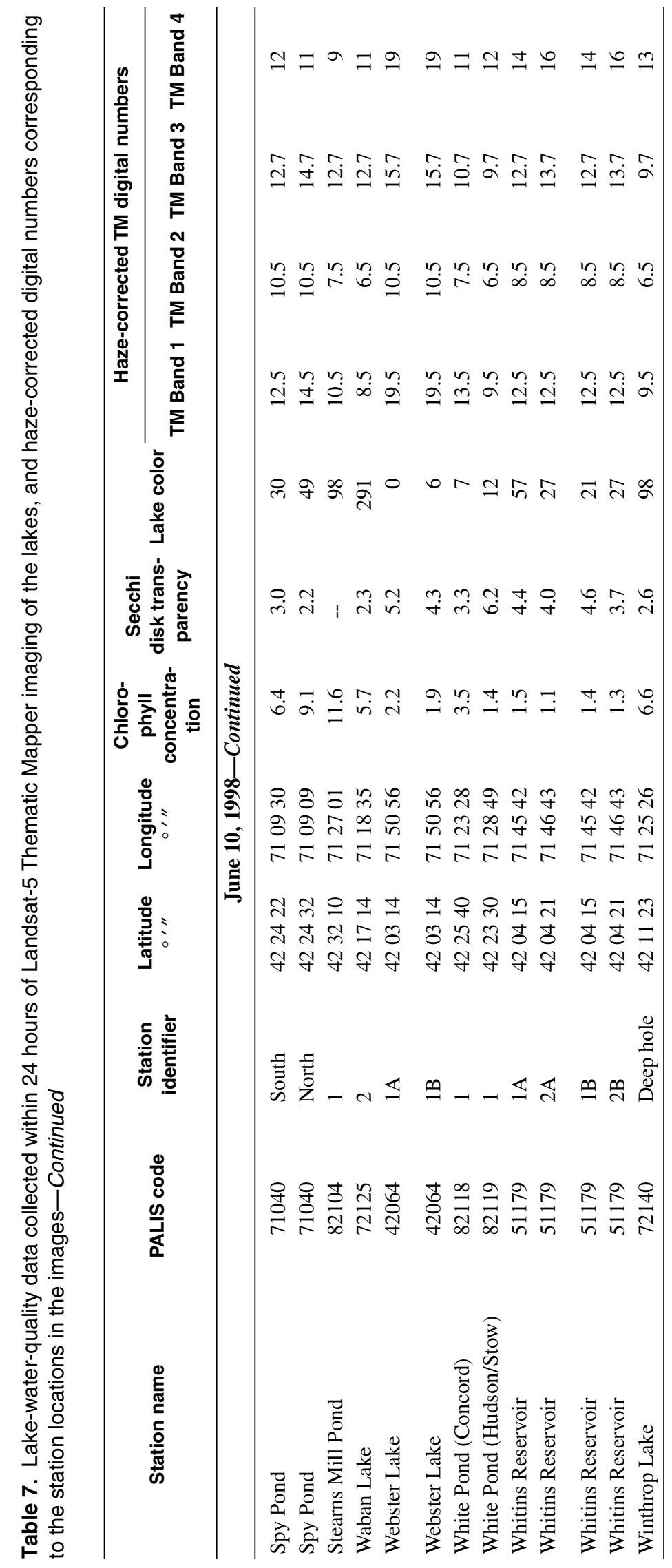

